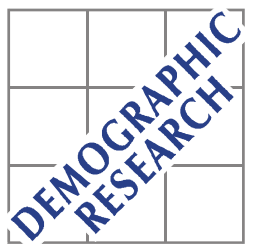

Demographic Research a free, expedited, online journal

of peer-reviewed research and commentary in the population sciences published by the Max Planck Institute for Demographic Research

Konrad-Zuse Str. 1, D-18057 Rostock · GERMANY

www.demographic-research.org

DEMOGRAPHIC RESEARCH

VOLUME 16, ARTICLE 3, PAGES 59-96

PUBLISHED 30 JANUARY 2007

http://www.demographic-research.org/Volumes/Vol16/3/

DOI: 10.4054/DemRes.2007.16.3

Research Article

The proximate determinants of fertility

and birth intervals in Egypt:

An application of calendar data

\title{
Angela Baschieri
}

\section{Andrew Hinde}

\section{(C) 2007 Baschieri \& Hinde}

This open-access work is published under the terms of the Creative Commons Attribution NonCommercial License 2.0 Germany, which permits use, reproduction \& distribution in any medium for non-commercial purposes, provided the original author(s) and source are given credit.

See http:// creativecommons.org/licenses/by-nc/2.0/de/ 


\section{Table of Contents}

$\begin{array}{lll}1 & \text { Introduction } & 60\end{array}$

2 Background and conceptual framework $\quad 62$

3 Data and sample $\quad 67$

4 Method 71

$5 \quad$ Results 73

$5.1 \quad$ 'Proximate' and 'socio-economic' models $\quad 75$

5.2 Effect of length of first interval and contraception on the second 83

5.3 Unobserved heterogeneity 84

$\begin{array}{lll}6 & \text { Conclusion } & 91\end{array}$

$7 \quad$ Acknowledgments $\quad 92$

$\begin{array}{ll}\text { References } & 93\end{array}$ 


\title{
The proximate determinants of fertility and birth intervals in Egypt: An application of calendar data
}

\author{
Angela Baschieri ${ }^{1}$ \\ Andrew Hinde ${ }^{2}$
}

\begin{abstract}
In this paper we use calendar data from the 2000 Egyptian Demographic and Health Survey (DHS) to assess the determinants of birth interval length among women who are in union. We make use of the well-known model of the proximate determinants of fertility, and take advantage of the fact that the DHS calendar data provide month-bymonth data on contraceptive use, breastfeeding and post-partum amenorrhoea, which are the most important proximate determinants among women in union. One aim of the analysis is to see whether the calendar data are sufficiently detailed to account for all non-random variation among individual women in birth interval duration, in that once they are controlled, the effect of background social, economic and cultural variables is not statistically significant. The results suggest that this is indeed the case, especially after a random effect term to account for the unobserved proximate determinants is included in the model. Birth intervals are determined mainly by the use of modern methods of contraception (the IUD being more effective than the pill). Breastfeeding and post-partum amenorrhoea both inhibit conception, and the effect of breastfeeding remains even after the period of amenorrhoea has ended.
\end{abstract}

\footnotetext{
${ }^{1}$ Centre for Population Studies, London School of Hygiene and Tropical Medicine, 49-51 Bedford Square, London, WC1B 3DP, United Kingdom. E-mail: angela.baschieri@1shtm.ac.uk

${ }^{2}$ School of Social Sciences and Southampton Statistical Science Research Institute (S3RI), University of Southampton, Southampton, SO17 1BJ, United Kingdom. E-mail: prah@ socsci.soton.ac.uk
} 


\section{Introduction}

It is now almost 30 years since John Bongaarts observed that the social, economic and cultural factors which influence fertility operate through what he called 'proximate determinants' (Bongaarts 1978). Changes in fertility are the direct result entirely of changes in these proximate determinants, which thus mediate the effect of changes in social, economic and cultural factors. This idea was not original to Bongaarts: 50 years ago Kingsley Davis and Judith Blake (Davis and Blake 1956) described the concept of 'intermediate variables' as a set of 'factors through which and only through which, social, economic, and cultural conditions can affect fertility' (Bongaarts 1982, p. 179). It was Bongaarts, however, who formalised the idea into a quantifiable model.

Using aggregate analysis with countries as units of analysis, Bongaarts (1982) demonstrated that, as the model posits, virtually all non-random variation in fertility is captured by differences in the proximate determinants. However, similar studies using individual-level data to analyse birth intervals have reached different results, and many authors have still found direct effects of social and economic variables on birth interval durations. Since, according to the model, the proximate determinants are exhaustive determinants of fertility outcomes, the existence of these residual direct effects has been explained by saying that the measurement of the proximate determinants is incomplete or inaccurate.

The most common set of data used to study fertility differentials in developing countries are the Demographic and Health Surveys (DHSs). These are large, nationally representative sample surveys collected for many countries around the world which provide information about fertility and family planning, including knowledge and current use of contraceptive methods, and detailed fertility histories with records of children's birth and death dates. Recent DHSs have also collected monthly calendar data, which comprise a longitudinal record of contraceptive use, breastfeeding and post-partum amenorrhoea for countries with relatively high contraceptive use. Although these calendar data provide unusually detailed information, few studies have hitherto used them (Curtis 1997, Curtis and Blanc 1997, Magnani, Rutenberg and McCann 1996, Steele and Curtis 2003, Steele, Curtis and Choe 1999, Zhang, Tsui and Suchindran 1999).

Studies of the quality of the DHS calendar data on contraception have shown that they are fairly reliable. Curtis (1997) compared the percentage of currently married women using contraception in current status data from an earlier survey and calendar data for corresponding time points for several countries. She found that calendar data quality is likely to vary across countries but that 'generally the estimates of prevalence obtained retrospectively from the calendar are in very close agreement with the corresponding current status estimates obtained from the earlier survey'(Curtis 1997, p. 
12). Leone (2002) performed a similar analysis using DHS data on current contraceptive use for north-east Brazil in 1991 and data from the calendar in the 1996 Brazilian DHS on current use at the time of the 1991 DHS and found similarly reassuring results. Strickler et al. (1997) had the unique opportunity to use data from 1995 Morocco Panel Survey to evaluate the reliability of the contraceptive history data collected in the calendar of the 1992 DHS. The Panel Survey consisted of a sub-sample of respondents from the DHS calendar. Both surveys included a five-year calendar, and the two calendars overlap for the period 1990-92. They found that the reporting of contraceptive use was fairly reliable, though data on contraceptive discontinuation and on complex histories were less so. Overall, their results suggest that the contraceptive use data are fairly robust, although estimates of contraceptive failure rates are likely to be less accurate than estimates of prevalence.

According to Bongaarts's (1982) framework, all the important variation in fertility is captured by variation by the proximate determinants of fertility. Therefore if we have good enough individual-level data on contraceptive use, breastfeeding and post-partum amenorrhoea and the other proximate determinants, we should be able to capture all variation in individual-level fertility. This means that once we have controlled for the proximate determinants, there should be no residual effect of social, economic and cultural factors. Since the DHS calendar data are among the most detailed data we possess, it is interesting to ask how much of the measurable variation in fertility they capture. If they are able to capture the majority of measurable variation, then the calendar data could be used to study the effect of each proximate determinant on fertility in each country for which a calendar is available, and will provide clear insights on the extent to which the proximate determinants affect fertility and hence the mechanisms through which social, cultural and economic factors work to affect fertility outcomes.

In the previous paragraph we use the phrase 'all measurable variation in fertility'. The proximate determinants as listed by Bongaarts can be divided into two groups: those which are measurable with the DHS calendar data and those which are difficult (or impossible) to measure. The first group includes those determinants generally thought to be most influential: those relating to exposure to the risk of sexual intercourse, contraceptive use and the duration of post-partum amenorrhoea. The second group includes such factors as the frequency of sexual intercourse. In our analysis, we attempt to control for the second group by introducing random effects to capture their variation among women.

One aim of this paper is therefore to assess whether the DHS calendar data are sufficiently detailed to enable us to capture 'all measurable variation' in birth interval durations. Using Egypt as a case study this paper first analyses the effect of the proximate determinants on the second birth interval. We then extend the analysis to the third birth interval to examine whether the effects of the proximate determinants change 
with birth order. Of course, Egypt has not been chosen at random. This paper forms part of a larger study of aspects of recent fertility change in that country, and our second aim is to discover what the main determinants of birth interval duration are in Egypt.

We limit the analysis to the second and third birth intervals as, according to the 2000 Egyptian Demographic and Health Survey (EDHS), few women who approve of family planning think that a newly married couple should use contraception to delay the first birth and only 0.3 percent of currently married women use modern methods of contraception before their first birth (El-Zanaty and Way 2001). More than 50 percent of married women conceive their first child within six months of their first marriage and in just over a year and half 75 percent do so. Among those women in the EDHS who had a first child, 50 percent conceived the second child within a year and half of the birth of the first child, and it took almost two years and a half for 75 percent of them to conceive their second child (Figure 1). Thus the first birth interval is shorter than the second and contraceptive use appears not to play a role in determining its length. Women start using contraception after the first birth.

In section 2 of this paper we present the background to the study and introduce the conceptual framework and the problem of model specification. Section 3 presents the data and considers issues of sample selection. Section 4 presents the method, and section 5 presents the major results.

\section{Background and conceptual framework}

Bongaarts (1982), using aggregate analysis with countries as units, demonstrated that virtually all important variation in fertility is captured by differences in marriage, breastfeeding, contraception, and induced abortion. He showed that the proportion of the variance explained, using the estimated total fertility rates to predict the actual total fertility rates, was 0.96 , a remarkable success for any social scientific model, even one using aggregate data (Rindfuss, Palmore and Bumpass 1987). Moreover, the residual variance in total fertility can plausibly be interpreted as being due to the other proximate determinants which were not included in the aggregate model. In other words, aggregate analyses have found, as they should theoretically, no direct effects of social and economic factors on fertility once the proximate determinants are taken into account.

Yet individual-level analyses of birth intervals have reached different results. Many authors have still found direct effects of social and economic variables on the birth interval durations after controlling for proximate variables (Bumpass, Rindfuss 
Figure 1: Kaplan-Meier estimate of the survival function for duration from marriage to the birth of the first child and for duration from the birth of the first child to the birth of second child: all ever married women, 2000 Egyptian Demographic and Health Survey (EDHS)

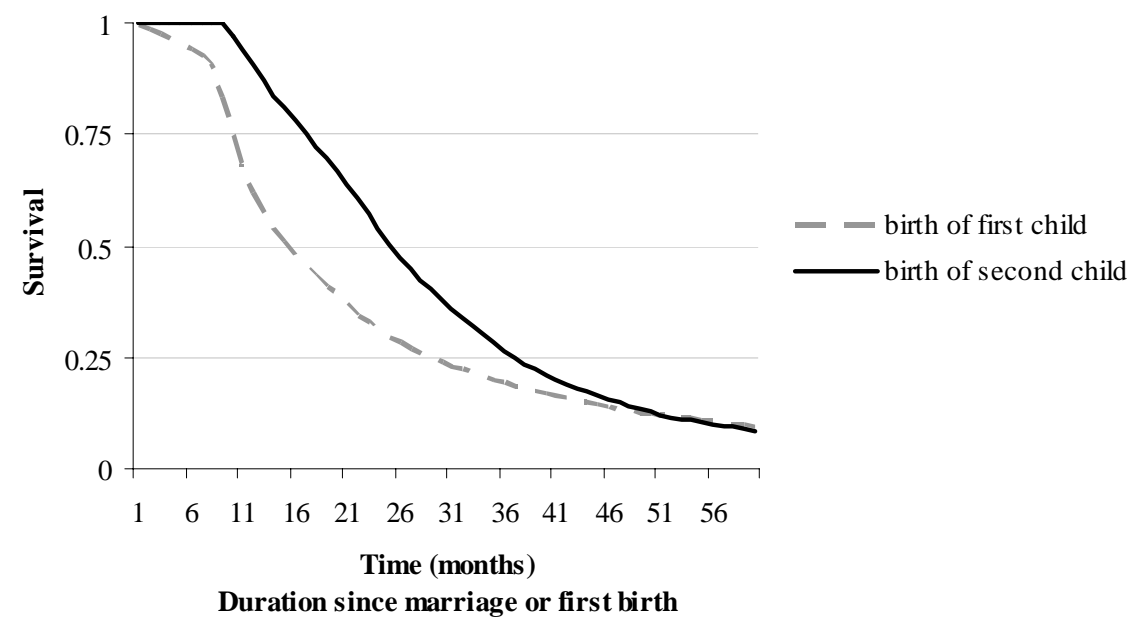

Notes. The Kaplan-Meier estimate for the first birth is based on all ever-married women aged 15-49 included in the 2000 EDHS (15,573 women), whereas the Kaplan-Meier estimate for the birth of second child is based on all the ever-married women who had had a first birth (14,164 women). For estimating the number of months by which 50 percent or 75 percent of women conceived a first or second child we subtract nine months from the number of months by which 50 or 75 percent of women give birth to their first or second child.

Source: 2000 Egyptian Demographic and Health Survey.

and James 1986, Palloni 1984, Trussell et al. 1985). Rindfuss, Palmore and Bumpass. (1987) argue that there could be three possible explanations for the discrepancy between theory and empirical micro-level analysis. One is that the conventionally-used measures of the proximate determinants of fertility are inadequate operationalisations of the theoretical constructs. For example, if a substantial proportion of all contraceptive use were not reported, observed contraceptive use patterns would miss much of contraception's mediating role. This is effectively a measurement-error problem. Second, because not all the proximate determinants are easily measurable, it is possible that important ones have been omitted from the models. This is really a specification error problem (Kallan and Udry 1986), but it is one which arises because of lack of data. Third, the effects of some of the intermediate variables or the socioeconomic variables might be curvilinear rather than linear. This is also a specification error problem, but is independent of the data. 
So far as data availability is concerned, therefore, the problem arises not just because the information that is collected is not accurate enough, but because some important variables are not collected at all. For example, to study the determinants of birth interval length one would ideally need information about intensity of breastfeeding, and contraceptive use over time (preferably on a month-by-month basis), and about frequency of intercourse. Unfortunately, only rarely does a study designed to look at fertility and family planning in developing countries collect information about breastfeeding and contraceptive use dynamics on a month-by-month basis in longitudinal format, and information on frequency of intercourse is not normally collected at all.

Several authors (Blossfeld and Rohwer 1995, Rindfuss, Palmore and Bumpass 1987) have stressed the fact that the exclusion of important covariates is likely to create mis-specification in the model and provide an incorrect estimate for the shape of the hazard with respect to time. Researchers have tried to cope with this problem of important omitted variables in the model by introducing an error term, and in duration analysis the residual becomes an important part of the model specification. Despite this theoretical rationale for introducing error terms in duration models, in the literature there are still opposing views about the appropriateness of their use (see section 4 for further discussion).

This paper will use data from the 2000 Egyptian Demographic and Health Survey (EDHS). Although DHS data are collected in a cross sectional format, for countries with high contraceptive use recent DHSs have collected retrospective monthly information about contraception, breastfeeding and post-partum amenorrhoea for the five years before the survey date. This study therefore makes use of detailed, month-by-month information on contraception (including data on the method being used in each month), breastfeeding behaviour and post partum amenorrhoea. The study uses a discrete-time hazard model with a gamma-distributed error term to account for unobserved heterogeneity, and discusses the implications for the shape of the hazard and survival functions of the introduction of the error term.

A key question for our analysis is whether there remains any direct effect of social, economic and cultural variables on the duration of the second birth interval in Egypt after controlling for the main proximate determinants using the DHS calendar data, and using an unobserved heterogeneity term to control for the remaining proximate determinants. In other words, we aim to see if, with improved measurement of the intermediate variables we can eliminate the direct effect of the socio-economic variables. In one sense the analysis is a test of the quality of the DHS calendar data on contraceptive use, breastfeeding and post-partum amenorrhoea. However we also aim to learn something about the relative contribution of the main proximate determinants to birth interval length in Egypt. 
Table 1 lists the proximate determinants of fertility as described by Bongaarts and shows how we control for them in our models. The first group of factors relates to exposure to the risk of sexual intercourse. These are principally the age at marriage and the time spent between marriages and after marriage. In our case, the Egyptian DHS only interviewed ever-married women, and preliminary analysis showed that almost all women were married before they had their first child and remained married until after their third child was born. We therefore restricted the analysis to women who fulfilled these criteria. We use the monthly calendar data to control for contraceptive use and the length of the post-partum infecundable interval. To control for variation in fecundity among women, we include information on the length of time elapsing between marriage and the first birth for women (the vast majority) who were not pregnant when they married. Only 0.3 percent of married women in the EDHS used contraception before the birth of their first child, so the length of the first birth interval is likely to be largely determined by a couple's fecundity. We do not have data on frequency of intercourse, nor on the duration of viability of ova and sperm. These will, we hope, be captured by the inclusion in the model of an unobserved heterogeneity term.

Finally, there is the question of induced abortion and pregnancies which end in miscarriage. The calendar data do include information about reported pregnancies which are terminated before a live birth. The majority of these were very short ( 80 per cent being under three months). It is likely that there were additional short pregnancies which ended in miscarriage which were not reported. It is in principle possible to control for these in the model by omitting those months during birth intervals which women spent pregnant in pregnancies which were not carried to term, but in the analysis reported here we chose not to do this. Such pregnancies were relatively few, but we acknowledge that ignoring them is a potential weakness in our analysis. However, it is worth pointing out that by ignoring them we make it more difficult for the calendar data to capture all the proximate determinants of fertility.

In the list of social, economic and cultural variables we include the respondent's level of education at first birth, region of residence, and the sex of the first child, as previous studies have found effects of those variables on birth interval length. We also included whether a woman was working or not before marriage for its possible correlation with women's work activity during the second birth interval. Not having longitudinal information about women's work status, we prefer to include in the analysis the work status before marriage rather than work status at the time of the survey to avoid a problem of endogeneity relating to current work status. A similar rationale is applied for the respondent's level of education at first birth, which has been calculated taking into consideration the Egyptian educational system (see note to Table 2). We include husband's educational level at the time of respondent's first birth to capture the effect of husband's socio-economic level. 
Separate consideration is needed of the effect of duration dependence or time since first birth on the risk of conception of the second child. Intuitively the risk of conception will be very low for the first month or two and increase and the decrease thereafter. However, it is not clear exactly what status duration dependence has in this conceptual framework and, whether indeed, its effect still exists after controlling for other socioeconomic and biological variables. We will include duration in our analysis in order to see the shape of the baseline hazard after controlling for intermediate variables and unobserved heterogeneity. However, we will bear in mind that duration is also likely to capture both unobservables as well as representing a measure of misspecification (Lancaster 1979).

\section{Table 1: Proximate determinants of fertility and our approach to controlling for them in the models of the second birth interval}

\begin{tabular}{ll}
\hline $\begin{array}{l}\text { Proximate determinant } \\
\begin{array}{l}\text { Age at entry into sexual unions, } \\
\text { time spent between and after unions }\end{array}\end{array}$ & How controlled for in the models \\
$\begin{array}{l}\text { Use of contraception } \\
\text { Using month-by-month method-specific } \\
\text { data on contraceptive use }\end{array}$ \\
$\begin{array}{l}\text { Not controlled for } \\
\text { Post-partum infecundability }\end{array}$ & $\begin{array}{l}\text { Month-by-month data on breastfeeding } \\
\text { and post-partum amenorrhoea introduced } \\
\text { as separate time-varying covariates }\end{array}$ \\
Spontaneous intra-uterine mortality & Not controlled for \\
Duration of viability of ova and sperm & Heterogeneity term \\
Frequency of sexual intercourse & Heterogeneity term \\
Fecundability & Length of first birth interval \\
\hline
\end{tabular}




\section{Data and sample}

The Demographic and Health Survey calendar consists of a matrix of rows and columns. Each row represents a particular month with the first row usually representing January of the fifth calendar year before the survey (for the 2000 EDHS, it represents January 1995). The columns are used to record different types of information for each month. In the 2000 EDHS calendar there are six columns. The first column contains month by month information about births, pregnancies and contraception, the second contains information about the reasons for discontinuation of contraceptive methods, the third about marriages and unions, the fourth about sources of family planning methods, the fifth about postpartum amenorrhoea and the sixth about breastfeeding.

In the present analysis we selected all women who had their first birth after the beginning of the calendar (January 1995), a total of 2,899 women. The event of interest is the conception leading to the second live birth. There are four possibilities (Figure 2): (1) the second birth occurs within the calendar period, (2) the second birth is after the survey date but conception happened before the survey date, (3) the second birth is conceived after the survey date, (4) there was no second conception even after the survey date. For the first group of women (who had a second birth within the calendar period) the time to conception is the time between the birth of first child and the birth of the second minus nine months. The event variable takes the value of 1 in the month that the second conception leading to a live birth occurs. The second group consists of women that conceived the second child before the end of the calendar but the birth happened after the survey date. For these women we use the information on pregnancy history in order to time the conception leading to the live birth. We assume that if a woman is pregnant for at least three months before the end of her calendar then the pregnancy will lead to the second live birth and the event variable takes the value of 1 in the month of conception. In this way we will also allow for miscarriage, since most miscarriages are in the first three months of pregnancy. In other words, conceptions which occur at least three months before the end of the calendar and which are not terminated before the end of the calendar are treated as events. We excluded information for the last three months of the calendar to allow for underreporting of the first trimester pregnancies at the time of the survey and to avoid including pregnancies that will end in termination shortly after the end of the calendar. For women who conceived their second child after the survey date (group 3) the duration is calculated between the birth of first child and a point three months before the survey date. In this case the event variable takes the value of 0 as the conception leading to a live birth did not occur within the period of observation. The same applies for those women that will never conceive a second child (group 4). In our sample, out of 2,899 women, 1,684 conceived their second child during the study period. 


\section{Figure 2: $\quad$ Selection procedures}



Note. In Group 1 there are 1,442 women, in Group 2 there are 242. As we do not experience the second birth for Group 3, we cannot distinguish between women that belong to Groups 3 or 4 , though we know that the total number of women for Groups 3 and 4 is 1,215 women.

Table 2 shows descriptive statistics for the variables included in the model with the categorization used. Column 1 shows the percentage distribution of women in the sample by background characteristics. Columns 2, 3 and 4 show, respectively, the 25th, 50th, and 75th percentiles of the second birth interval in months by selected background characteristics derived from Kaplan-Meier estimates. In other words column 2 shows the number of months by which 25 per cent of the relevant subgroup of women had their second birth, column 3 shows the number of months by which the 50 per cent of the same women had their second birth, and column 4 the number of months by which 75 per cent had their second birth. 
Table 2: Percentage distribution, and 25th, 50th and 75th percentiles of the interval between first birth and conception of second birth by selected background characteristics of women that had a first birth after 1 January 1995

\begin{tabular}{|c|c|c|c|c|}
\hline \multirow[t]{2}{*}{ Characteristic } & \multirow[t]{2}{*}{ Percentage } & \multicolumn{3}{|c|}{ Percentiles of second birth interval (months) } \\
\hline & & 25th & 50th & 75th \\
\hline \multicolumn{5}{|l|}{ Age (years) } \\
\hline Less than 18 & 10.4 & 13 & 22 & 32 \\
\hline $18-22$ & 42.7 & 13 & 20 & 29 \\
\hline $22-27$ & 35.6 & 14 & 23 & 34 \\
\hline Over 27 & 11.3 & 13 & 23 & 39 \\
\hline \multicolumn{5}{|c|}{ Respondent's education at first birth } \\
\hline No education & 25.9 & 12 & 19 & 30 \\
\hline Primary & 12.6 & 13 & 20 & 32 \\
\hline Secondary & 50.0 & 15 & 24 & 34 \\
\hline Higher & 11.5 & 13 & 22 & 32 \\
\hline \multicolumn{5}{|l|}{ Region of residence } \\
\hline Urban Governorates & 20.0 & 15 & 25 & 39 \\
\hline Urban Lower Egypt & 13.0 & 17 & 25 & 36 \\
\hline Rural Lower Egypt & 28.7 & 14 & 21 & 30 \\
\hline Urban Upper Egypt & 10.1 & 13 & 23 & 36 \\
\hline Rural Upper Egypt & 22.7 & 11 & 18 & 28 \\
\hline Frontier Governorates & 5.5 & 12 & 21 & 28 \\
\hline \multicolumn{5}{|l|}{ Sex of first child } \\
\hline Male & 51.5 & 13 & 23 & 34 \\
\hline Female & 48.5 & 13 & 21 & 30 \\
\hline \multicolumn{5}{|c|}{ Respondent worked before marriage } \\
\hline Yes & 18.9 & 14 & 24 & 35 \\
\hline No & 81.1 & 13 & 21 & 32 \\
\hline \multicolumn{5}{|l|}{ Partner's education } \\
\hline No education & 15.9 & 12 & 20 & 33 \\
\hline Some education & 84.1 & 14 & 22 & 32 \\
\hline \multicolumn{5}{|l|}{ First child alive } \\
\hline Yes & 96.1 & 14 & 22 & 33 \\
\hline No & 3.9 & 5 & 9 & 18 \\
\hline \multicolumn{5}{|c|}{ Months between marriage and first birth } \\
\hline Less than 19 months & 72.0 & 14 & 23 & 32 \\
\hline More than 19 months & 28.0 & 12 & 20 & 32 \\
\hline Less than 12 months & 51.2 & 14 & 24 & 33 \\
\hline More than 12 months & 48.8 & 12 & 20 & 30 \\
\hline
\end{tabular}


Baschieri \& Hinde: The proximate determinants of fertility and birth intervals in Egypt

Table 2 Notes. The total number of women is 2,899. Information about educational attainment at the time of the first birth has been derived from the mothers' age at first birth using the World Higher Education System database (which can be found in the UNESCO website) and assuming that all the women that had some level of education entered schooling at the official entry age for primary education ( 6 years), and proceeded to further levels of education at the usual ages (14 years for secondary and 19 years for higher education). For example, suppose a mother of age 22 is reported to have 'higher education' at the time of the survey. If she had her first child at age 18, then because the entry age for higher education in Egypt is at least 19 years of age, the educational level of this woman when she had her first birth was 'secondary'. In fact, the educational level at the time of the first birth is different from that reported at the time of the survey for only four women who had higher education level at the time of the survey and secondary education at the time of their first birth. This is probably due to the fact that our sample relates only to women that had their first child after 1 January 1995, leaving a maximum of five years gap between the first birth and survey date. Moreover, most women in Egypt complete their education before they have their first child.

Source. 2000 Egyptian Demographic and Health Survey.

The duration by which 50 per cent of women with no education had conceived their second child is 19 months and with an increasing level of education the birth interval is longer, but this trend reverses for women with higher education, so that the number of months by which 50 per cent of women with higher education had conceived their second child is lower than the corresponding duration for women with secondary education (Table 2). The same result is confirmed for other percentiles. Women living in rural Upper Egypt have the shortest birth intervals, followed by women living in Frontier Governorates and rural Lower Egypt. There appears to be a 'sex-of-first-child' effect: if the first child was female the number of months by which 50 per cent of women had the second birth is shorter ( 21 months) than if the first child was male ( 23 months). Amongst respondents who worked before marriage the number of months by which 25,50 or 75 per cent had a second birth is longer than for those women who did not work before marriage. Moreover, women who had a partner with no education seem to have shorter intervals than those who had a partner with some education. A quite substantial difference appears by survival status of first child. If the first child dies the number of months by which 25,50 and 75 per cent of women had a second birth is considerably shorter (five, nine and 18 months respectively) than if the first child remains alive (14, 22 , and 33 months respectively). The mean length of time from marriage to the birth of the first child is 19 months for the women in our sample (which by definition excludes women who had not given birth to their first child before the survey). Among women for whom the length of time from marriage to the first child is less than the mean length, the second birth-conception interval is longer. The same applies if instead of the mean we use the median first birth interval (12 months). 


\section{Method}

We apply a discrete time hazard model of the length of time between first birth and the conception leading to the second live birth. This model specification will allow for a flexible baseline hazard, so there is no need to assume a functional form of the effect of duration. The duration will be broken into $k$ categories (say 0-2 months, 3-5 months, etc...) during each of which the risk of pregnancy is assumed constant for individuals with the same values of the covariates. The degree of flexibility of the baseline hazard will depend on the number of duration dummies in the model.

The discrete time hazard rate is defined as:

$$
h_{i t}=\operatorname{Pr}\left[T_{i}=t \mid T_{i} \geq t, x_{i t}\right],
$$

where $x_{i t}$ is a vector of regressor variables (covariates), some of which can be fixed covariates, and others can be time-varying. $T_{i}$ is a discrete random variable representing the time at which the end of the spell occurs.

We chose to estimate the hazard by applying a discrete time hazard model using a logistic functional form. As Jenkins (1995) suggested, if we reorganize the data in a person-months format, the model likelihood has exactly the same form as that for a standard binary logit regression model. Furthermore this model specification will facilitate the introduction of time-varying covariates in the model. This type of model also allows for censoring in the data.

The hazard rate is defined as follows:

$$
h_{i t}=1 /\left\{1+\exp \left[-\theta(t)-\beta^{\prime} x_{i t}\right]\right\} \Leftrightarrow \log \left[h_{i t} /\left(1-h_{i t}\right)\right]=\theta(t)+\beta^{\prime} x_{i t},
$$

where $\theta(t)$ allows the hazard to vary with time. As has been previously mentioned this specification facilitates the inclusion of time-varying covariates, since $x_{i t}$ can include both time-varying and fixed covariates. Furthermore the time varying covariates and fixed covariates can have fixed effects as well as time-varying effects.

We treated breastfeeding practices, post-partum amenorrhoea, and contraception as time-varying covariates with fixed effects, and all the other variables as fixed covariates with fixed effects. During the analysis several interactions of fixed-effect variables and time-varying variables with duration dummies were tried, but none was significant. In all the models we partitioned the interval between the birth of the first child and the pregnancy leading to the birth of the second into several categories: $0-2,3-5,6-9,10-12$, 
13-15, 16-18, 19-23, 24-29, 30-36, 37-42, and 43-60 months. Rodriguez (1984) has shown that the estimated effects of covariates are quite insensitive to the choice of partition. We chose the duration categories to be narrow at the beginning of the interval as other studies (Hobcraft and McDonald 1984) have shown that the hazards change quickly at the beginning of the interval, mainly because the effect of lactation changes vary rapidly after birth.

As previously mentioned, in the literature there is diverging opinion about the value of including unobserved heterogeneity in the model. Some authors argue (Jenkins 1997; Lancaster 1979) that failing to account for unobserved heterogeneity in the model will result in an over-estimation of the degree of negative duration dependence in the (true) baseline hazard, and an under-estimate of the degree of positive dependence. This is because women whose unobservable characteristics render them 'high-risk', and likely to experience the event of interest have short durations and leave the sample, so that at higher durations the risk set is increasingly composed of women whose unobservable characteristics make them unlikely to experience the event of interest. The result is that failure to account for unobserved heterogeneity will lead the analyst to overestimate the hazard at short durations and underestimate the hazard at longer durations. Moreover, failing to account for unobserved heterogeneity will bias the parameter estimates of regressors as well.

On the other hand, a drawback of accounting for unobserved heterogeneity in the model is that the parameter estimates can be highly sensitive to the assumed parametric form of the error term (Blossfeld and Rohwer 1995). As an example Heckman and Singer (1982) estimated four different unobserved heterogeneity models: one with a normal, one with a log-normal, and one with a gamma distribution of the error term, as well a model with a non-parametric specification of the disturbance. They found that the parameter estimates provided by these models were surprisingly different. In other words, as Blossfeld and Rohwer (1995) suggest, the misspecification of the duration variables caused by neglecting the error term might simply be replaced by misspecification of the parametric distribution of the error term.

It has been suggested, however, that with a flexible specification of the duration dependence, i.e. in our case the 10 duration dummies, the misspecification can be avoided. McDonald and Egger (1990) have suggested that the unobserved heterogeneity in the analysis of birth intervals could allow us to measure individual fecundity. In our case, we believe that the duration of the first birth interval provides an approximate measure of fecundity. Nevertheless, McDonald and Egger's general point is valid: including unobserved heterogeneity in the model will avoid us having to assume that there are no omitted covariates in the model, and will also allow measurement of individual unobserved fecundity. In other words, since there are proximate determinants 
which we have not observed, the inclusion of the heterogeneity term allows us to control for their effects.

We present the results both of models without accounting for unobserved heterogeneity and models accounting for unobserved heterogeneity for the purposes of comparison and we discuss the implications of the introduction of unobserved heterogeneity in the model. In the model which accounts for unobserved heterogeneity, the hazard rate is specified:

$$
\log \left[h_{i t} /\left(1-h_{i t}\right)\right]=\theta(t)+\beta^{\prime} X_{i t}+\varepsilon_{i}
$$

where $\varepsilon_{i}$ is the unobserved heterogeneity term.

The models are estimated using the pgmhaz command in STATA developed by Jenkins (1997). This command estimates, by maximum likelihood, two discrete time grouped duration data proportional hazard models one of which incorporates a gamma mixture distribution to summarize individual unobserved heterogeneity (or 'frailty'). The two models estimated are (1) the Prentice and Gloeckler (1978) model and (2) the Prentice and Gloeckler (1978) model incorporating a gamma mixture distribution to summarize unobserved individual heterogeneity, as proposed by Meyer (1990). The Prentice-Gloeckler-Meyer models are described by Stewart (1996).

\section{Results}

In the presentation of the results we shall use two statistics employed by Rodriguez and Hobcraft (1983) in their illustrative analysis of life tables. As originally defined, the quintum is the proportion of women that have their next birth within five years (60 months). The trimean is a measure of the average birth interval among those women who have their next child within five years (measured by the quintum). The trimean, originally developed by Tukey (1977), contains more information about the shape of the distribution than the median as it includes in its formula the first and third quartiles, thus allowing the detection of asymmetries in the distribution. It is defined as:

$$
T=\left(q_{1}+2 q_{2}+q_{3}\right) / 4
$$

where $T$ is the trimean and $q_{1}, q_{2}$, and $q_{3}$ are the durations by which 25,50 and 75 per cent respectively of those women who go on to have their next child within five years have had their next child. When the right tail is long, as is true for the distribution of 
pregnancies in a birth interval, the trimean will be higher (slightly) than the median. Rodriguez and Hobcraft (1983) considered the birth interval length and calculated the quintum and trimean for each parity.

In the present study we modify the definition so that it relates to the birth-pregnancy interval (Trussell, Vaughan and Farid, 1988). Hence, the quintum is the estimated proportion becoming pregnant within 51 months and is a direct estimate of the proportion giving birth within five years, and the trimean is a measure of the average birthpregnancy interval of those women who conceived their second child within 51 months of giving birth to their first. Other measurements that could be calculated to report the dispersion of the data include the spread (or inter-quartile range). The spread, in this case, is the difference between the duration by which 25 per cent of women conceive their second child and the duration by which 75 per cent of women conceive their second child.

Figure 3 shows the Kaplan-Meier estimate of the survival function from first birth to conception of the second birth for the whole sample. From the Kaplan-Meier estimate the quintum, trimean and spread may be calculated, and these are shown for the whole sample in Table 3, column 1. The quintum is 0.91 , which means that 91 per cent of women in our sample that had conceived a first birth conceived the second child within 51 months, with an average first birth-pregnancy interval of almost 20 months. Furthermore 25 per cent of women conceive their second child within a year (11.9 months) and 50 per cent of women in just over a year and a half (19.6 months).

\section{Table 3: Quintum, median, trimean, and spread from Kaplan-Meier estimate} and duration-only model (durations in months)

\begin{tabular}{lcc}
\hline & Kaplan-Meier estimate & Duration only model \\
\hline Quintum (Q) & 0.91 & 0.89 \\
$q_{1}$ & 11.9 & 12.8 \\
$q_{2}$ Median & 19.6 & 21.7 \\
$q_{3}$ & 27.9 & 29.9 \\
Trimean (T) & 19.7 & 21.5 \\
Spread (S) & 15.9 & 17.1 \\
\hline
\end{tabular}


Figure 3: Kaplan-Meier estimate of the survival function for the interval between first birth and second conception for women that had a first child after 1 January 1995

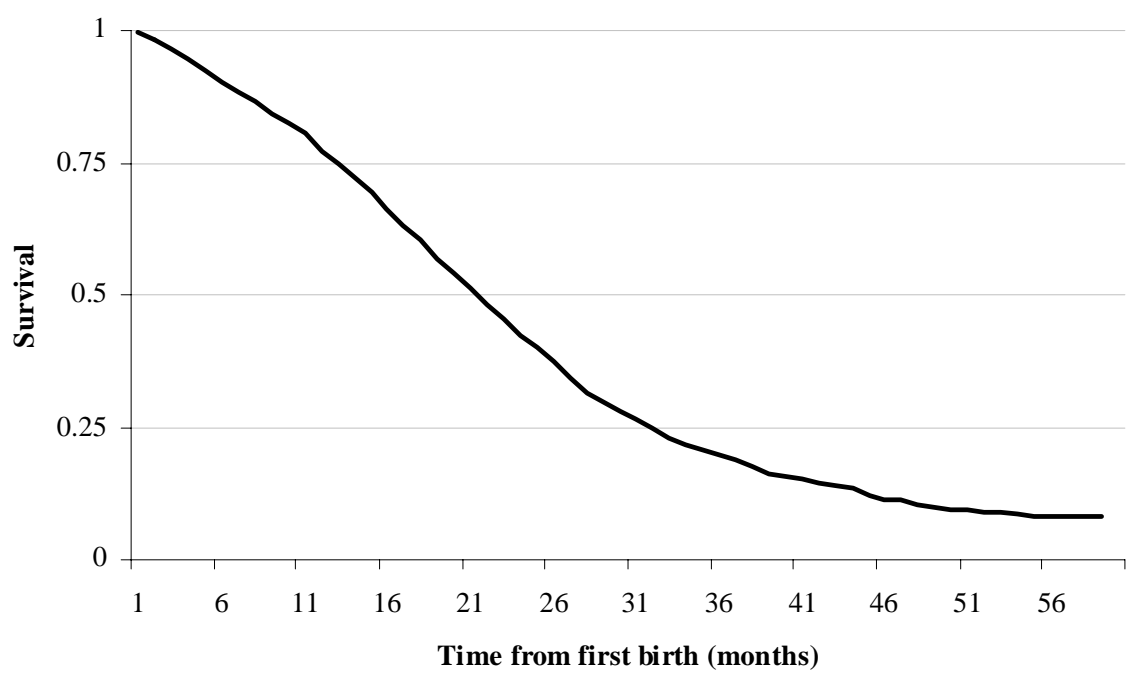

Source: 2000 Egyptian Demographic and Health Survey.

\section{1 'Proximate' and 'socio-economic' models}

We estimate four different models. Model 1 includes only duration, and tests whether the raw hazard varies with duration since the first birth. Model 2 includes only variables measuring the proximate determinants (age of mother at first birth, breastfeeding, amenorrhoea, use of types of contraception, and the length of the interval between marriage and first birth). Model 3 includes only social, economic and cultural variables (region of residence, respondent's education, husband's education, whether or not the respondent worked before marriage and sex and survival status of the first child). Model 4 includes both sets of variables. In this way we can compare the 'socioeconomic' model to the 'proximate' model and, by comparing Models 3 and 4, see if the social, economic and cultural covariates become insignificant when the proximate determinants are also in the model. 
Consider first Model 1 (Table 4), with only duration as a covariate. Figure 4 shows the shape of the hazard of conception for this model, and demonstrates that the risk of conceiving the second child increases almost monotonically until two years after the birth of the first child, and then decreases. The quintum of this 'duration-only' model is 0.89 (89 per cent of women became pregnant within 51 months) and the trimean is 21.5 (Table 3).

\section{Figure 4: Estimated hazard of conception of second birth (duration-only model)}



Note: In this figure the hazard at duration t months, $\mathrm{h}(\mathrm{t})$, is calculated using model 1 in Table 4 using the equation $h(t)=\exp \left(b_{0}+b_{t}\right) /\left[\left(1+\exp \left(b_{0}+b_{t}\right)\right]\right.$, where $b_{0}$ is the estimated value of the constant $(-4.753)$ and $b_{t}$ is the estimated value of the parameter applying to duration t. Thus, for example, the hazard at duration $24-29$ months is equal to $\exp (-4.753+2.139) /[(1+$ $\exp (-4.753+2.139)]=0.0682$. 
Comparing the 'proximate' Model 2 with Model 1 we see that adding the proximate determinants, not surprisingly, dramatically improves the fit of the model. The effect of duration also changes, because the estimated duration effect in Model 1 relates to all women, whereas that in Model 2 relates to a 'baseline' group of women who are aged 1822 years at the time of the first birth and who are not using contraception, not breastfeeding and not amenorrheic. Because breastfeeding, amenorrhoea and contraceptive use vary with duration, the proportion of the risk-set who are in the 'baseline' group also varies with duration. The results of Model 2 clearly justify the inclusion in the model of both the information on breastfeeding and amenorrhoea, in that breastfeeding significantly reduces the risk of conception even among non-amenorrheic women. The use of contraception greatly decreases the hazard of conception, with the intra-uterine device (IUD) being slightly more effective in this respect than the pill or other methods.

Model 3, the 'socio-economic' model, has a much lower explanatory power than Model 2. Although several variables significantly affect the hazard in Model 3, in all but one case the effects are reduced in magnitude in Model 4, which includes both proximate and socio-economic variables. However, Model 4 does mark a significant improvement on the 'proximate' model (Model 2). Performing a likelihood-ratio test we have:

$$
\begin{aligned}
&(2\{\text { Log-Likelihood (full model) }- \text { Log-Likelihood (proximate only model })\} \\
&=2 \times(-6004)-(-6031) \\
&=54
\end{aligned}
$$

with 12 degrees of freedom $(p<0.0005)$. Model 4 with both socio-economic variables and proximate variables thus performs better than the 'proximate' model.

The effect of the survival status of the first child on the monthly hazard of conception differs across the models. In Model 4 the monthly risk of conception increases by 20 per cent where the first child is alive compared with the case where the first child is dead. However, in the 'socio-economic' model, the effect of the survival of the first child appears to be strongly negative. One possible explanation of this is that while the first child survives, women rely on breastfeeding for contraception. We added to Model 3 a term measuring the interaction between the duration and survival status of the first child. The results (not shown) were that the effect of the death of the first child was greatest at durations 6-9 months. 
Table 4: $\quad$ Parameter estimates of discrete time hazard models for duration to conception of second child.

\begin{tabular}{|c|c|c|c|c|}
\hline Covariates & $\begin{array}{l}\text { Model } 1 \\
\text { Duration } \\
\text { only }\end{array}$ & $\begin{array}{l}\text { Model } 2 \\
\text { Proximate } \\
\text { variables } \\
\text { only }\end{array}$ & $\begin{array}{l}\text { Model } 3 \\
\text { Socio- } \\
\text { economic } \\
\text { variables only }\end{array}$ & $\begin{array}{l}\text { Model } 4 \\
\text { Both proximate and } \\
\text { socio-economic } \\
\text { variables }\end{array}$ \\
\hline \multicolumn{5}{|c|}{ Duration since first birth (months) } \\
\hline $1-2$ & 0 & 0 & 0 & 0 \\
\hline $3-5$ & $\begin{array}{l}0.908 \\
(5.55)^{\star *}\end{array}$ & $\begin{array}{l}0.935 \\
(5.17)^{\star *}\end{array}$ & $\begin{array}{l}0.919 \\
(5.62)^{\star *}\end{array}$ & $\begin{array}{l}0.943 \\
(5.21)^{* *}\end{array}$ \\
\hline $6-9$ & $\begin{array}{l}0.981 \\
(6.14)^{\star *}\end{array}$ & $\begin{array}{l}0.998 \\
(5.56)^{\star *}\end{array}$ & $\begin{array}{l}1.006 \\
(6.28)^{\star *}\end{array}$ & $\begin{array}{l}1.006 \\
(5.60)^{\star *}\end{array}$ \\
\hline $10-12$ & $\begin{array}{l}1.220 \\
(7.45)^{\star *}\end{array}$ & $\begin{array}{l}1.218 \\
(6.61)^{\star *}\end{array}$ & $\begin{array}{c}1.258 \\
(7.67)^{\star *}\end{array}$ & $\begin{array}{c}1.223 \\
(6.62)^{\star *}\end{array}$ \\
\hline $13-15$ & $\begin{array}{l}1.440 \\
(8.84)^{\star *}\end{array}$ & $\begin{array}{l}1.414 \\
(7.64)^{\star *}\end{array}$ & $\begin{array}{l}1.486 \\
(9.11)^{\star *}\end{array}$ & $\begin{array}{c}1.420 \\
(7.65)^{\star *}\end{array}$ \\
\hline $16-18$ & $\begin{array}{c}1.708 \\
(10.55)^{\star *}\end{array}$ & $\begin{array}{l}1.612 \\
(8.70)^{\star *}\end{array}$ & $\begin{array}{c}1.769 \\
(10.89)^{\star *}\end{array}$ & $\begin{array}{c}1.613 \\
(8.67)^{\star *}\end{array}$ \\
\hline $19-23$ & $\begin{array}{c}1.903 \\
(12.17)^{\star \star}\end{array}$ & $\begin{array}{l}1.582 \\
(8.65)^{\star \star}\end{array}$ & $\begin{array}{c}1.984 \\
(12.66)^{\star *}\end{array}$ & $\begin{array}{l}1.580 \\
(8.57)^{\star *}\end{array}$ \\
\hline $24-29$ & $\begin{array}{c}2.139 \\
(13.56)^{\star *}\end{array}$ & $\begin{array}{l}1.529 \\
(8.14)^{\star *}\end{array}$ & $\begin{array}{l}2.247 \\
(14.20)^{\star *}\end{array}$ & $\begin{array}{l}1.535 \\
(8.07)^{\star *}\end{array}$ \\
\hline $30-36$ & $\begin{array}{c}1.961 \\
(11.54)^{\star *}\end{array}$ & $\begin{array}{l}1.202 \\
(6.04)^{\star *}\end{array}$ & $\begin{array}{l}2.086 \\
(12.23)^{\star *}\end{array}$ & $\begin{array}{l}1.226 \\
(6.08)^{\star *}\end{array}$ \\
\hline $37-42$ & $\begin{array}{c}1.843 \\
(9.12)^{\star *}\end{array}$ & $\begin{array}{c}0.914 \\
(4.01)^{\star *}\end{array}$ & $\begin{array}{c}1.983 \\
(9.76)^{\star \star}\end{array}$ & $\begin{array}{c}0.943 \\
(4.09)^{* *}\end{array}$ \\
\hline $43-60$ & $\begin{array}{l}1.674 \\
(7.51)^{\star *}\end{array}$ & $\begin{array}{l}0.725 \\
(2.94)^{* *}\end{array}$ & $\begin{array}{l}1.863 \\
(8.31)^{* *}\end{array}$ & $\begin{array}{l}0.771 \\
(3.09)^{\star *}\end{array}$ \\
\hline \multicolumn{5}{|l|}{ Age group } \\
\hline Less than 18 years & & $\begin{array}{l}-0.207 \\
(2.40)^{*}\end{array}$ & $\begin{array}{l}-0.171 \\
(1.98)^{*}\end{array}$ & $\begin{array}{l}-0.167 \\
(1.90)\end{array}$ \\
\hline $18-22$ years & & & & \\
\hline $22-27$ years & & $\begin{array}{c}0.072 \\
(1.23)\end{array}$ & $\begin{array}{l}-0.085 \\
(1.42)\end{array}$ & $\begin{array}{c}0.054 \\
(0.87)\end{array}$ \\
\hline Over 27 years & & $\begin{array}{l}-0.068 \\
(0.73)\end{array}$ & $\begin{array}{l}-0.195 \\
(2.12)^{*}\end{array}$ & $\begin{array}{l}-0.125 \\
(1.25)\end{array}$ \\
\hline $\begin{array}{l}\text { Time (months) from } \\
\text { marriage to first birth }\end{array}$ & & $\begin{array}{l}-0.013 \\
(8.30)^{* *}\end{array}$ & & $\begin{array}{l}-0.012 \\
(7.67)^{\star *}\end{array}$ \\
\hline \multicolumn{5}{|l|}{ Amenorrheic } \\
\hline Yes & & $\begin{array}{l}-1.226 \\
(11.66)^{\star \star}\end{array}$ & & $\begin{array}{l}-1.237 \\
(11.72)^{\star *}\end{array}$ \\
\hline No & & 0 & & 0 \\
\hline \multicolumn{5}{|l|}{ Breastfeeding } \\
\hline Yes & & $\begin{array}{l}-0.477 \\
(7.15)^{\star \star}\end{array}$ & & $\begin{array}{l}-0.504 \\
(7.10)^{\star *}\end{array}$ \\
\hline No & & 0 & & 0 \\
\hline \multicolumn{5}{|c|}{ Type of contraceptive method being used } \\
\hline $\begin{array}{l}\text { None or traditional } \\
\text { Pill }\end{array}$ & & $\begin{array}{l}0 \\
-2.147 \\
(14.58)^{* *}\end{array}$ & & $\begin{array}{l}0 \\
-2.190 \\
(14.80)^{* *}\end{array}$ \\
\hline
\end{tabular}


Table 4: $\quad$ (Continued)

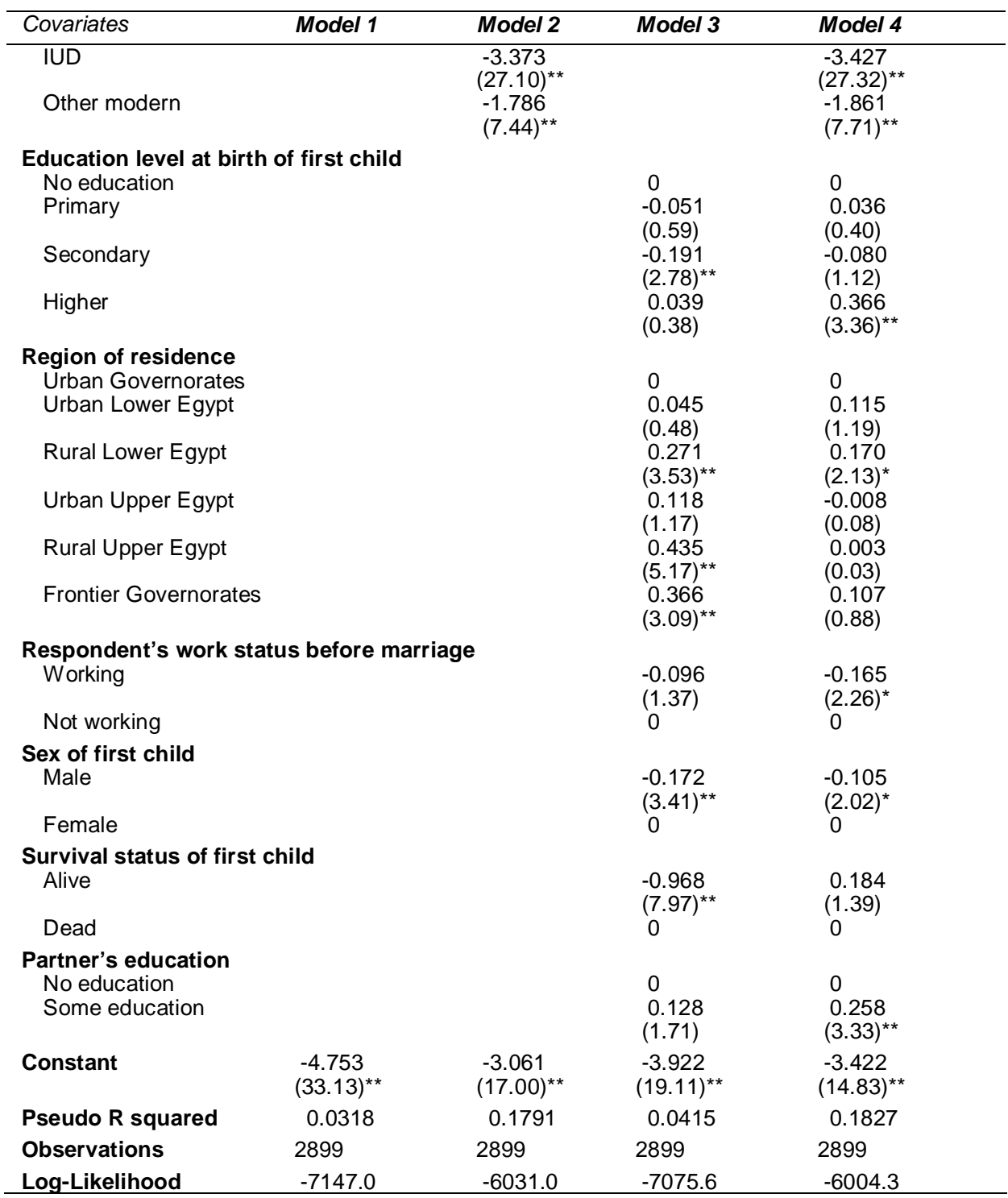

Note. Absolute value of $z$-statistics in parentheses. * significant at $5 \%$; ${ }^{\star \star}$ significant at $1 \%$. 
Figure 5 shows the estimated shape of the hazard for four types of women: (1) a woman that did not breastfeed, who was never subject to post-partum amenorrhoea and who did not use contraception over the study period; (2) a woman who used the pill but did not breastfeed and was never subject to post-partum amenorrhoea; (3) a woman who used the IUD, did not breastfeed and who was never subject to post-partum amenorrhoea; and (4) a woman who used 'other modern methods', who did not breastfeed and who was never subject to post-partum amenorrhoea. Despite the fact that the shapes of the hazards displayed below refer to hypothetical women, Figure 5 helps to reveal the effectiveness of different types of contraceptive method. The IUD is the most effective method of contraception, whereas the pill is a less effective method.

\section{Figure 5: Estimated hazard of conception of second birth for selected women}

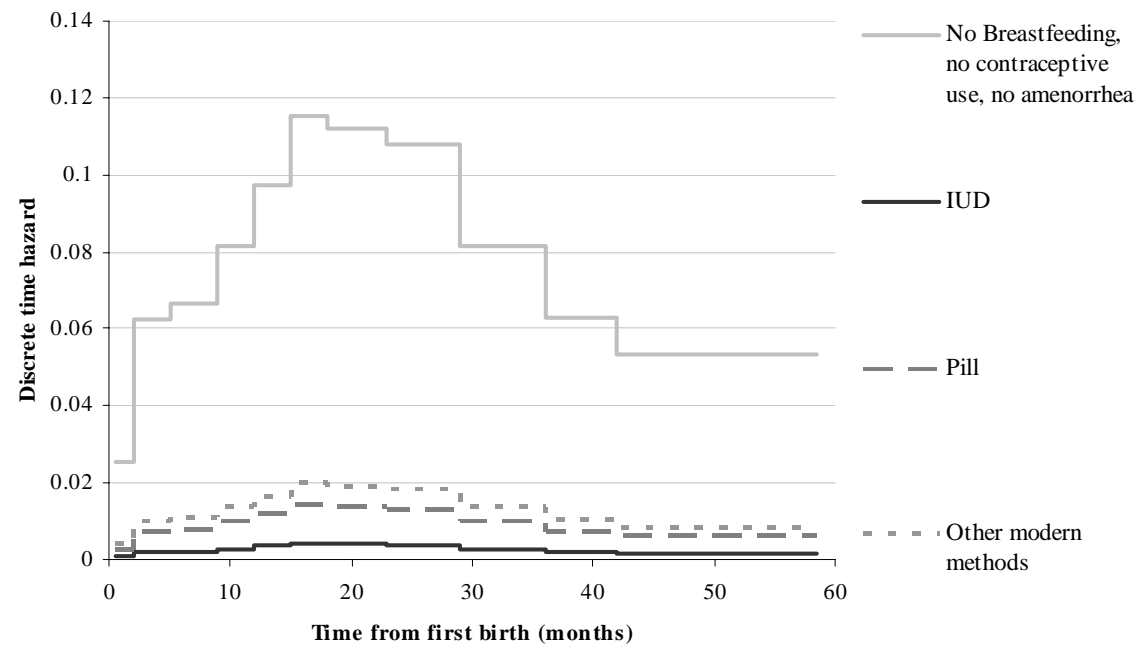

Note: In this figure the hazard at duration t months, $h(t)$, is calculated using Model 4 in Table 4 using the equation $h(t)=\exp (b X) /[(1+\exp (b X)]$ where $b$ is a vector of parameter estimates and $X$ is the appropriate covariate vector. The covariate vector used in the calculations relates to the reference category on all covariates except duration since first birth, contraceptive use and the time (in months) from marriage to first birth. The time from marriage to first birth was set at 19 for all women. 
Figures 6 and 7 show the hazard and survivor functions of four more 'realistic' groups of women. All these groups of women were both breastfeeding and amenorrheic for the first four months after the birth of the first child. After this the amenorrhoea ceased, but they kept on breastfeeding until month 13 after the first child was born. The first group did not use contraception at all during the observation period. The second group used the IUD for 18 months after the period of amenorrhoea ended (they were both breastfeeding and using contraception for nine months, after which they continued to use the IUD for another 9 months). The third and fourth groups are like the second group, except that they used the pill and 'other modern methods' respectively instead of the IUD. Calculations of the quintum and trimean of fertility for the groups of women in Figures 6 and 7 show that there is a difference of two months in the average birthconception interval between women using IUDs and women using the pill or 'other modern methods' of contraception, suggesting differences in contraceptive failure rates between women using the IUD and women using the pill or 'other modern methods'. The IUD is the most reliable method of contraception in Egypt.

\section{Figure 6: Estimated hazard function of conception of second birth for selected women}



Note. See text for detailed description of the characteristics of women in each category. The hazards in this figure are derived from those in Figure 5. 


\section{Figure 7: Estimated survival function of conception of second birth for selected women}

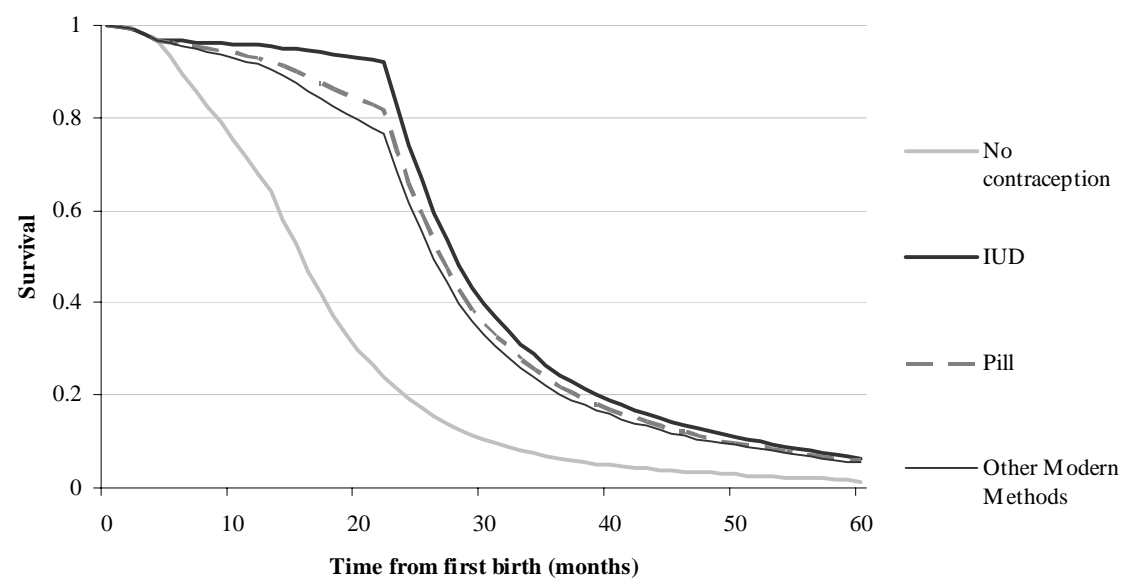

Note. See text for detailed description of the characteristics of women in each category. The survival function for a particular group of women at duration $\mathrm{t}, \mathrm{S}(\mathrm{t})$, is derived from the relevant hazard function in Figure 6 using the equation $S(t)=\exp \left[-\int_{0}^{t} h(s) d s\right]$, where $\mathrm{h}(\mathrm{s})$ is the appropriate hazard in Figure 6.

It is clear from the results so far that the proximate determinants, as captured by the DHS calendar, account for a substantial proportion of the variation in the length of the second birth interval. However, there is still quite a lot of unexplained variation, some of which appears to be accounted for by the 'direct' effects of social, economic and cultural variables - which should not, according to the proximate determinants model, be present. Looking at the effect of socio-economic variables in Model 4 on the risk of conception we can see that the respondent's and husband's education, whether or not the respondent worked before marriage, the sex of the first child, and region of residence have a significant effect on hazard of conception, though only respondent's and husband's education are significant at the 1 per cent level. Women with higher education have shorter birth intervals than uneducated women, the relative risk of conception being 44 per cent higher $(100 \times$ [ $\exp (0.366)-1])$. If the first child is male the relative risk of conception decreases by 10 per cent, resulting in a longer second birth interval than if the first child was female. If the respondent worked before marriage the relative risk of conception of second child is 15 per cent lower, resulting in a longer birth interval. If the 
partner of the respondent has some level of education the relative risk of conception is 29 per cent higher, resulting in a shorter birth interval.

One possible explanation of the continued significance of some social, economic and cultural variables in Model 4 is that, although the framework of Bongaarts (1982) still holds in general, including the socio-economic variables improves our measurement of the impact of intermediate variables. For example, if the first child is a boy, one would expect more contraceptive use because of a reduced need to have a second child quickly compared to the situation when the first child is a girl. However the 'sex-of-first-child' effect is still significant after accounting for contraceptive use and duration of breastfeeding. This might be because, for example, boys are breastfed more intensely than girls, or that contraception is used more carefully after a boy than a girl. Furthermore, higher educated women appear to have a higher risk of conception compared to women with no education. This could be explained by the fact that higher educated women are those who rely more on traditional methods, such as periodic abstinence (Esseghairi 2003).

The gradual erosion of the contraceptive effect of breastfeeding as the first child grows up also explains why no multicollinearity problem exists with the introduction in the model of both breastfeeding information and the period of post-partum amenorrhoea. The results confirmed previous findings on the effect of breastfeeding net of amenorrhoea on fertility (Jain et al. 1970) and show the importance of including both information on breastfeeding and post-partum amenorrhoea in model specification in birth interval analysis. In addition, no multicollinearity problem appears also to exist between respondent's and husband's educational level, and between respondent's work status before marriage and respondent's level of education.

\subsection{Effect of length of first interval and contraception on the second birth interval}

We estimated three additional models to show the changes in the effect of other covariates on the hazard of conception of the second birth after having excluded the contraception variables, and to assess if the effect of the length of the interval between marriage and birth (the first birth interval) is linear and if this effect changes with the exclusion of contraceptive use variables. Model 5 is the same as Model 4 but without the contraceptive use variables. Model 6 is a variation of Model 4 in which the length of the first birth interval is allowed to have a non-linear (quadratic) effect on the hazard. Model 7 is, in effect, a combination of Models 5 and 6, in that it both excludes the contraceptive use variables and allows the length of the first birth interval to have a quadratic effect.

The results of Models 5-7 are shown in Table 5. The results suggest that the length of the first interval has a non-linear effect on the length of second interval if we do not 
include contraceptive use variables (see Model 7). If we include contraceptive use variables in the model, the effect of the first birth interval length on the second birth interval is linear, as illustrated by the non-significant coefficient for the square of length of birth interval in Model 6. This result might be interpreted by suggesting that women who experience a short first birth interval consider themselves to be especially fecund and therefore are especially careful in their use of contraception to delay the second birth. Conversely, women who found it difficult to conceive their first child (that is, they had a long first birth interval), might rely on their low fecundity to produce an acceptably long second birth interval.

Comparing Models 4 and 5, there are changes in the effect of several socioeconomic covariates when contraceptive use is excluded. Without the contraceptive use variables, the effect of having a secondary education is significant, whereas the effect of having higher education becomes insignificant. The effect of being resident in rural Upper Egypt and Frontier Governorates and the survival status of first child are significant when contraceptive use is excluded, but not when it is included. The opposite is true of husband's education.

\subsection{Unobserved heterogeneity}

We re-estimated Model 4 (the combined 'socio-economic' and 'proximate' model) incorporating the term for gamma-distributed unobserved heterogeneity. The results (Table 6) show that the unobserved heterogeneity parameter is significant suggesting that individual-level unobserved heterogeneity should be part of the model. The parameter estimates on the social and economic covariates change very little when the unobserved heterogeneity term is added, suggesting that there is little correlation between the unobservables and the socio-economic covariates included in the model. It therefore seems plausible to conclude that the heterogeneity term is largely picking up unobserved variations in fecundity due, for example, to physiological factors or coital frequency.

In the model with unobserved heterogeneity (Table 6, column 2) the duration parameters do not decrease with duration after 19-23 months, as they do in the model without unobserved heterogeneity (Table 6 , column 1 ). Instead they are roughly constant (Figure 8). This is due to the fact that the model without unobserved heterogeneity over estimates the degree of negative duration dependence because of a selection effect whereby 'high risk' women fail faster and the survivors are increasingly drawn from a 'low risk' group. The unobserved heterogeneity term controls for this selection effect, with the result that different duration segments contain women with similar levels of unmeasured risk. Moreover, once we account for unobserved heterogeneity all the socio- 
economic variables except husband's education lose their significance, whereas proximate variables such as amenorrhoea and contraceptive use become more significant.

In Table 6 (columns 3 and 4) are also shown the results for a 'combined' model of the third birth interval with and without unobserved heterogeneity. The results for the third birth interval show that all the variation in birth interval length is captured by the proximate determinants. The effects of work and education which were found to be significant for the second birth interval are not significant here. In order to test formally for differences between the second birth interval and third birth interval model a likelihood ratio test has been performed. The log-likelihood of a model for the data for the second and third intervals pooled together and the sum of log-likelihoods of the separate models for the second and the third interval have been used. This procedure can only be approximate for several reasons. First, when performing the likelihood ratio test only a subset of the parameters included in the models in Table 6 can be considered. In particular, survival status of the first child is less relevant for the third birth interval as for the second birth interval, and the effect of the variable 'sex of the first child' cannot be directly compared across both intervals as the option of a mixed pair is possible in the case of the third birth interval. Moreover, pooling together the women who had a second birth and a third birth implies that the observations will be dependent of each other.

With these caveats, the results suggest that the two models are significantly different. The log-likelihood of the pooled model is 7252.67 and the sum of the loglikelihoods for the models of the second and third birth intervals taken separately is 7219.17. A likelihood ratio test performed using twice the difference between the loglikelihoods gives a value of 67 with 29 degrees of freedom $(p=0.0005)$. Part of the difference between the models is due to the fact that the women selected for the third birth interval analysis are only those who had a second birth in the five years prior the survey date (as opposed to women who had a first birth within this window in the analysis for the second birth interval) and for this reason not only tend to belong to an older cohort but are also a 'more' selected group of women as they already had their second birth. 
Table 5: Parameter estimates for discrete time hazard models for duration to conception of second child

\begin{tabular}{|c|c|c|c|c|}
\hline Covariate & Model 4 & $\begin{array}{l}\text { Model } 5 \\
\text { Without } \\
\text { contraceptive } \\
\text { use variables }\end{array}$ & $\begin{array}{l}\text { Model } 6 \\
\quad \text { With non- } \\
\text { linear effect } \\
\text { of first birth } \\
\text { interval }\end{array}$ & $\begin{array}{l}\text { Model } 7 \\
\quad \text { With non-linear effect } \\
\text { of first birth interval and } \\
\text { without contraceptive } \\
\text { use variables }\end{array}$ \\
\hline \multicolumn{5}{|c|}{ Duration since first birth(months) } \\
\hline & 0 & 0 & 0 & 0 \\
\hline $3-5$ & $\begin{array}{l}0.943 \\
(5.21)^{\star *}\end{array}$ & $\begin{array}{l}0.779 \\
(4.34)^{\star *}\end{array}$ & $\begin{array}{l}0.942 \\
(5.20)^{\star *}\end{array}$ & $\begin{array}{c}0.775 \\
(4.32)^{\star \star}\end{array}$ \\
\hline $6-9$ & $\begin{array}{l}1.006 \\
(5.60)^{\star *}\end{array}$ & $\begin{array}{c}0.785 \\
(4.40)^{\star *}\end{array}$ & $\begin{array}{c}1.005 \\
(5.59)^{\star *}\end{array}$ & $\begin{array}{l}0.779 \\
(4.37)^{\star *}\end{array}$ \\
\hline $10-12$ & $\begin{array}{c}1.223 \\
(6.62)^{\star *}\end{array}$ & $\begin{array}{c}0.987 \\
(5.39)^{\star *}\end{array}$ & $\begin{array}{c}1.221 \\
(6.61)^{\star *}\end{array}$ & $\begin{array}{c}0.979 \\
(5.35)^{\star *}\end{array}$ \\
\hline $13-15$ & $\begin{array}{l}1.420 \\
(7.65)^{\star *}\end{array}$ & $\begin{array}{l}1.162 \\
(6.32)^{\star *}\end{array}$ & $\begin{array}{l}1.418 \\
(7.64)^{\star \star}\end{array}$ & $\begin{array}{c}1.154 \\
(6.28)^{\star \star}\end{array}$ \\
\hline $16-18$ & $\begin{array}{c}1.613 \\
(8.67)^{\star *}\end{array}$ & $\begin{array}{l}1.390 \\
(7.57)^{\star *}\end{array}$ & $\begin{array}{l}1.612 \\
(8.67)^{\star *}\end{array}$ & $\begin{array}{c}1.385 \\
(7.54)^{\star *}\end{array}$ \\
\hline $19-23$ & $\begin{array}{l}1.580 \\
(8.57)^{\star *}\end{array}$ & $\begin{array}{l}1.379 \\
(7.58)^{\star *}\end{array}$ & $\begin{array}{c}1.578 \\
(8.56)^{\star *}\end{array}$ & $\begin{array}{l}1.373 \\
(7.55)^{\star *}\end{array}$ \\
\hline $24-29$ & $\begin{array}{l}1.535 \\
(8.07)^{\star *}\end{array}$ & $\begin{array}{l}1.452 \\
(7.76)^{\star *}\end{array}$ & $\begin{array}{c}1.534 \\
(8.07)^{\star *}\end{array}$ & $\begin{array}{l}1.447 \\
(7.73)^{* *}\end{array}$ \\
\hline $30-36$ & $\begin{array}{c}1.226 \\
(6.08)^{\star \star}\end{array}$ & $\begin{array}{l}1.252 \\
(6.30)^{\star *}\end{array}$ & $\begin{array}{c}1.225 \\
(6.07)^{\star *}\end{array}$ & $\begin{array}{c}1.243 \\
(6.26)^{\star *}\end{array}$ \\
\hline $37-42$ & $\begin{array}{c}0.943 \\
(4.09)^{* *}\end{array}$ & $\begin{array}{l}1.155 \\
(5.09)^{\star *}\end{array}$ & $\begin{array}{l}0.941 \\
(4.08)^{* *}\end{array}$ & $\begin{array}{c}1.141 \\
(5.03)^{* *}\end{array}$ \\
\hline $43-60$ & $\begin{array}{l}0.771 \\
(3.09)^{* *}\end{array}$ & $\begin{array}{c}1.039 \\
(4.22)^{\star *}\end{array}$ & $\begin{array}{c}0.770 \\
(3.09)^{* *}\end{array}$ & $\begin{array}{c}1.030 \\
(4.18)^{\star *}\end{array}$ \\
\hline \multicolumn{5}{|l|}{ Age group } \\
\hline Less than 18 years & $\begin{array}{l}-0.167 \\
(1.90)\end{array}$ & $\begin{array}{l}-0.204 \\
(2.35)^{*}\end{array}$ & $\begin{array}{l}-0.164 \\
(1.86)\end{array}$ & $\begin{array}{l}-0.188 \\
(2.16)^{\star}\end{array}$ \\
\hline $18-22$ years & 0 & 0 & 0 & 0 \\
\hline $22-27$ years & $\begin{array}{c}0.054 \\
(0.87)\end{array}$ & $\begin{array}{l}-0.061 \\
(1.01)\end{array}$ & $\begin{array}{c}0.052 \\
(0.83)\end{array}$ & $\begin{array}{l}-0.074 \\
(1.23)\end{array}$ \\
\hline Over 27 years & $\begin{array}{l}-0.125 \\
(1.25)\end{array}$ & $\begin{array}{l}-0.077 \\
(0.80)\end{array}$ & $\begin{array}{l}-0.122 \\
(1.21)\end{array}$ & $\begin{array}{l}-0.054 \\
(0.56)\end{array}$ \\
\hline \multicolumn{5}{|c|}{ Educational level at birth of first child } \\
\hline No education & 0 & 0 & 0 & 0 \\
\hline Primary & $\begin{array}{c}0.036 \\
(0.40)\end{array}$ & $\begin{array}{l}-0.069 \\
(0.79)\end{array}$ & $\begin{array}{c}0.039 \\
(0.44)\end{array}$ & $\begin{array}{l}-0.058 \\
(0.67)\end{array}$ \\
\hline Secondary & $\begin{array}{l}-0.080 \\
(1.12)\end{array}$ & $\begin{array}{l}-0.239 \\
(3.44)^{\star *}\end{array}$ & $\begin{array}{l}-0.077 \\
(1.08)\end{array}$ & $\begin{array}{l}-0.224 \\
(3.21)^{\star *}\end{array}$ \\
\hline Higher & $\begin{array}{l}0.366 \\
(3.36)^{\star *}\end{array}$ & $\begin{array}{l}-0.003 \\
(0.03)\end{array}$ & $\begin{array}{l}0.370 \\
(3.39)^{\star *}\end{array}$ & $\begin{array}{l}0.016 \\
(0.15)\end{array}$ \\
\hline \multicolumn{5}{|l|}{ Region of residence } \\
\hline Urban Governorates & 0 & 0 & 0 & 0 \\
\hline Urban Lower Egypt & $\begin{array}{c}0.115 \\
(1.19)\end{array}$ & $\begin{array}{c}0.024 \\
(0.26)\end{array}$ & $\begin{array}{c}0.114 \\
(1.18)\end{array}$ & $\begin{array}{c}0.021 \\
(0.22)\end{array}$ \\
\hline Rural Lower Egypt & $\begin{array}{c}0.170 \\
(2.13)^{*}\end{array}$ & $\begin{array}{c}0.287 \\
(3.71)^{* *}\end{array}$ & $\begin{array}{c}0.170 \\
(2.13)^{*}\end{array}$ & $\begin{array}{c}0.291 \\
(3.77)^{* *}\end{array}$ \\
\hline Urban Upper Egypt & $\begin{array}{l}-0.008 \\
(0.08)\end{array}$ & $\begin{array}{r}0.121 \\
(1.20)\end{array}$ & $\begin{array}{l}-0.007 \\
(0.06)\end{array}$ & $\begin{array}{r}0.127 \\
(1.26)\end{array}$ \\
\hline
\end{tabular}


Table 5: (Continued)

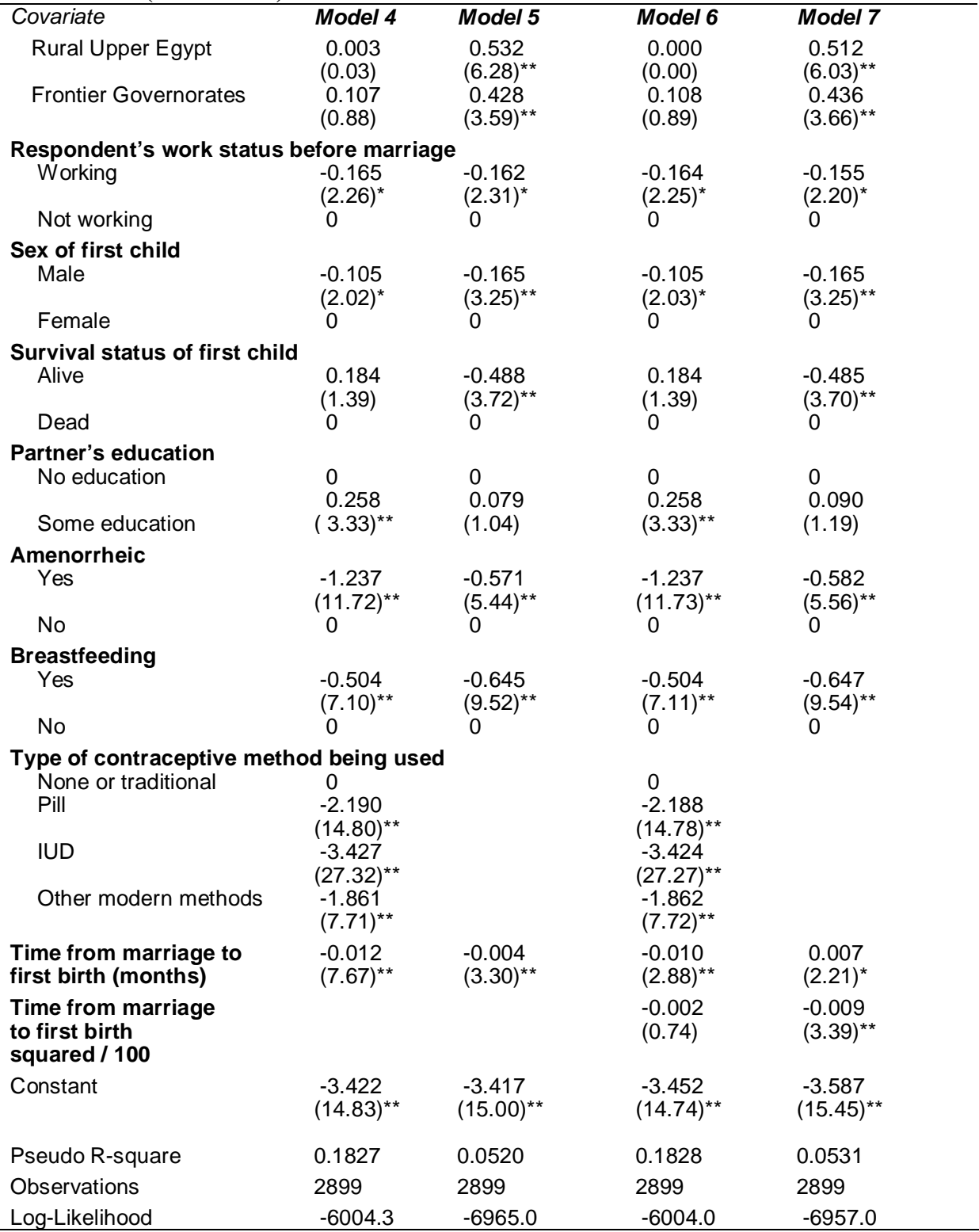

Note. Absolute value of $z$-statistics in parentheses. ${ }^{*}$ significant at $5 \% ;{ }^{* *}$ significant at $1 \%$. 
Table 6: Discrete-time hazard models of time to conception of second and third births for models with and without accounting for unobserved heterogeneity

\begin{tabular}{|c|c|c|c|c|}
\hline Covariate & $\begin{array}{l}\text { Second birth } \\
\text { without } \\
\text { unobserved } \\
\text { heterogeneity }\end{array}$ & $\begin{array}{l}\text { Second birth } \\
\text { with gamma- } \\
\text { distributed } \\
\text { heterogeneity }\end{array}$ & $\begin{array}{l}\text { Third birth } \\
\text { without } \\
\text { unobserved } \\
\text { heterogeneity }\end{array}$ & $\begin{array}{l}\text { Third birth with } \\
\text { gamma- } \\
\text { distributed } \\
\text { heterogeneity }\end{array}$ \\
\hline \multicolumn{5}{|c|}{ Duration since previous birth (months) } \\
\hline $1-2$ & 0 & 0 & 0 & 0 \\
\hline $3-5$ & $\begin{array}{c}0.943 \\
(5.21)^{\star \star}\end{array}$ & $\begin{array}{c}1.057 \\
(5.60)^{\star \star}\end{array}$ & $\begin{array}{c}0.756 \\
(2.01)^{\star *}\end{array}$ & $\begin{array}{c}1.074 \\
(2.51)^{\star \star}\end{array}$ \\
\hline $6-9$ & $\begin{array}{c}1.006 \\
(5.60)^{* *}\end{array}$ & $\begin{array}{c}1.291 \\
(6.85)^{* *}\end{array}$ & $\begin{array}{l}1.417 \\
(3.99)^{\star *}\end{array}$ & $\begin{array}{l}1.936 \\
(4.70)^{* *}\end{array}$ \\
\hline $10-12$ & $\begin{array}{c}1.223 \\
(6.62)^{* *}\end{array}$ & $\begin{array}{l}1.642 \\
(8.43)^{* *}\end{array}$ & $\begin{array}{c}1.060 \\
(2.73)^{\star *}\end{array}$ & $\begin{array}{l}1.851 \\
(4.13)^{\star *}\end{array}$ \\
\hline $13-15$ & $\begin{array}{c}1.420 \\
(7.65)^{\star *}\end{array}$ & $\begin{array}{c}1.965 \\
(9.92)^{\star *}\end{array}$ & $\begin{array}{c}1.551 \\
(4.10)^{* *}\end{array}$ & $\begin{array}{c}2.484 \\
(5.56)^{\star *}\end{array}$ \\
\hline $16-18$ & $\begin{array}{c}1.613 \\
(8.67)^{\star *}\end{array}$ & $\begin{array}{c}2.260 \\
(11.26)^{\star \star}\end{array}$ & $\begin{array}{c}1.865 \\
(4.93)^{\star *}\end{array}$ & $\begin{array}{l}3.005 \\
(6.51)^{\star \star}\end{array}$ \\
\hline $19-23$ & $\begin{array}{c}1.580 \\
(8.57)^{\star *}\end{array}$ & $\begin{array}{c}2.303 \\
(11.24)^{\star *}\end{array}$ & $\begin{array}{l}1.660 \\
(4.34)^{\star *}\end{array}$ & $\begin{array}{l}3.046 \\
(6.27)^{\star *}\end{array}$ \\
\hline $24-29$ & $\begin{array}{l}1.535 \\
(8.07)^{\star *}\end{array}$ & $\begin{array}{c}2.401 \\
(11.06)^{\star *}\end{array}$ & $\begin{array}{c}1.557 \\
(3.79)^{\star *}\end{array}$ & $\begin{array}{l}3.133 \\
(5.95)^{\star *}\end{array}$ \\
\hline $30-36$ & $\begin{array}{c}1.226 \\
(6.08)^{\star *}\end{array}$ & $\begin{array}{c}2.397 \\
(10.06)^{\star *}\end{array}$ & $\begin{array}{c}1.731 \\
(4.00)^{* *}\end{array}$ & $\begin{array}{l}3.409 \\
(6.04)^{\star *}\end{array}$ \\
\hline $37-42$ & $\begin{array}{c}0.943 \\
(4.09)^{\star *}\end{array}$ & $\begin{array}{l}2.318 \\
(8.38)^{\star *}\end{array}$ & $\begin{array}{c}1.336 \\
(2.08)^{* *}\end{array}$ & $\begin{array}{l}3.303 \\
(4.10)^{\star *}\end{array}$ \\
\hline $43-60$ & $\begin{array}{c}0.771 \\
(3.09)^{\star *}\end{array}$ & $\begin{array}{l}2.438 \\
(7.69)^{\star *}\end{array}$ & $\begin{array}{c}0.617 \\
(0.57)\end{array}$ & $\begin{array}{c}3.313 \\
(2.40)^{*}\end{array}$ \\
\hline \multicolumn{5}{|l|}{ Age group } \\
\hline Less than 18 years & $\begin{array}{l}-0.167 \\
(1.90)^{*}\end{array}$ & $\begin{array}{l}-0.209 \\
(1.60)\end{array}$ & $\begin{array}{c}0.110 \\
(0.59)\end{array}$ & $\begin{array}{c}0.152 \\
(0.53)\end{array}$ \\
\hline $18-22$ years & 0 & & 0 & \\
\hline 22-27 years & $\begin{array}{c}0.054 \\
(0.87)\end{array}$ & $\begin{array}{c}0.079 \\
(0.87)\end{array}$ & $\begin{array}{c}0.135 \\
(0.90)\end{array}$ & $\begin{array}{c}0.468 \\
(2.10)^{*}\end{array}$ \\
\hline Over 27 years & $\begin{array}{l}-0.125 \\
(1.25)\end{array}$ & $\begin{array}{c}0.026 \\
(0.18)\end{array}$ & $\begin{array}{l}-0.441 \\
(1.65)^{*}\end{array}$ & $\begin{array}{c}0.023 \\
(0.06)\end{array}$ \\
\hline \multicolumn{5}{|c|}{ Educational level at birth of first child } \\
\hline No education & 0 & 0 & 0 & 0 \\
\hline Primary & $\begin{array}{c}0.036 \\
(0.40)\end{array}$ & $\begin{array}{c}0.018 \\
(0.14)\end{array}$ & $\begin{array}{l}-0.200 \\
(1.02)\end{array}$ & $\begin{array}{l}-0.306 \\
(1.08)\end{array}$ \\
\hline Secondary & $\begin{array}{l}-0.080 \\
(1.12)\end{array}$ & $\begin{array}{l}-0.157 \\
(1.51)\end{array}$ & $\begin{array}{c}0.018 \\
(0.11)\end{array}$ & $\begin{array}{l}0.015 \\
(0.06)\end{array}$ \\
\hline Higher & $\begin{array}{c}0.366 \\
(3.36)^{\star *}\end{array}$ & $\begin{array}{c}0.255 \\
(1.63)\end{array}$ & $\begin{array}{c}0.148 \\
(0.48)\end{array}$ & $\begin{array}{c}0.068 \\
(0.17)\end{array}$ \\
\hline \multicolumn{5}{|l|}{ Region of residence } \\
\hline Urban Governorates & 0 & 0 & 0 & 0 \\
\hline Urban Lower Egypt & $\begin{array}{r}0.115 \\
(1.19) \\
\end{array}$ & $\begin{array}{r}0.111 \\
(0.79) \\
\end{array}$ & $\begin{array}{c}0.253 \\
(0.92) \\
\end{array}$ & $\begin{array}{l}-0.180 \\
(0.47)\end{array}$ \\
\hline
\end{tabular}


Table 6: (Continued)

\begin{tabular}{|c|c|c|c|c|}
\hline Rural Lower Egypt & 0.170 & 0.185 & 0.046 & -0.343 \\
\hline Urban Upper Egypt & $\begin{array}{l}-0.008 \\
(0.08)\end{array}$ & 0.185 & $\begin{array}{l}-0.036 \\
(0.14)\end{array}$ & $\begin{array}{l}-0.246 \\
(0.65)\end{array}$ \\
\hline Rural Upper Egypt & 0.003 & 0.117 & 0.126 & -0.139 \\
\hline Frontier Governorates & $\begin{array}{r}(0.03) \\
0.107 \\
(0.88)\end{array}$ & $\begin{array}{c}(0.92) \\
0.131 \\
(0.73)\end{array}$ & $\begin{array}{l}(0.56) \\
-0.054 \\
(0.19)\end{array}$ & $\begin{array}{l}(0.45) \\
-0.075 \\
(0.18)\end{array}$ \\
\hline \multicolumn{5}{|c|}{ Respondent's work status before marriage } \\
\hline Working & $\begin{array}{l}-0.165 \\
(2.26)^{\star}\end{array}$ & $\begin{array}{l}-0.174 \\
(1.62)\end{array}$ & $\begin{array}{c}0.114 \\
(0.60)\end{array}$ & $\begin{array}{l}-0.048 \\
(0.18)\end{array}$ \\
\hline Not working & 0 & 0 & & \\
\hline \multicolumn{5}{|l|}{ Sex of first (two) child(ren) } \\
\hline Male & $\begin{array}{l}-0.105 \\
(2.02)^{*}\end{array}$ & $\begin{array}{l}-0.105 \\
(1.39)\end{array}$ & $\begin{array}{c}0.219 \\
(1.24)\end{array}$ & $\begin{array}{c}0.088 \\
(0.35)\end{array}$ \\
\hline Female & 0 & 0 & & \\
\hline Mixed pair & n.a & n.a. & $\begin{array}{l}0.065 \\
(0.43)\end{array}$ & $\begin{array}{c}0.057 \\
(0.26)\end{array}$ \\
\hline \multicolumn{5}{|c|}{ Survival status of first child } \\
\hline Alive & $\begin{array}{c}0.184 \\
(1.39)\end{array}$ & $\begin{array}{l}0.068 \\
(0.34)\end{array}$ & $\begin{array}{l}-0.380 \\
(2.41)^{*}\end{array}$ & $\begin{array}{l}-0.688 \\
(2.79)^{* *}\end{array}$ \\
\hline Dead & 0 & 0 & 0 & 0 \\
\hline \multicolumn{5}{|l|}{ Partner's education } \\
\hline No education & 0 & 0 & 0 & 0 \\
\hline Some education & $\begin{array}{l}0.258 \\
(3.33)^{\star *}\end{array}$ & $\begin{array}{l}0.254 \\
(2.24)^{*}\end{array}$ & $\begin{array}{l}-0.093 \\
(0.57)\end{array}$ & $\begin{array}{l}-0.141 \\
(0.57)\end{array}$ \\
\hline $\begin{array}{l}\text { Time from marriage to } \\
\text { first birth }\end{array}$ & $\begin{array}{l}-0.012 \\
(7.67)^{\star *}\end{array}$ & $\begin{array}{l}-0.014 \\
(6.81)^{\star *}\end{array}$ & $\begin{array}{l}-0.001 \\
(0.17)\end{array}$ & $\begin{array}{l}-0.001 \\
(0.23)\end{array}$ \\
\hline \multicolumn{5}{|l|}{ Amenorrheic } \\
\hline Yes & $\begin{array}{l}-1.237 \\
(11.72)^{\star *}\end{array}$ & $\begin{array}{l}-1.483 \\
(12.96)^{* *}\end{array}$ & $\begin{array}{l}-1.321 \\
(6.34)^{* *}\end{array}$ & $\begin{array}{l}-1.607 \\
(6.85)^{\star \star}\end{array}$ \\
\hline No & 0 & 0 & 0 & 0 \\
\hline \multicolumn{5}{|l|}{ Breastfeeding } \\
\hline Yes & $\begin{array}{l}-0.504 \\
(7.10)^{* *}\end{array}$ & $\begin{array}{l}-0.575 \\
(6.62)^{* *}\end{array}$ & $\begin{array}{l}-0.678 \\
(4.31)^{\star *}\end{array}$ & $\begin{array}{l}-0.778 \\
(3.89)^{* *}\end{array}$ \\
\hline No & 0 & 0 & 0 & 0 \\
\hline \multicolumn{5}{|c|}{ Type of contraceptive method being used } \\
\hline None or traditional & & 0 & 0 & 0 \\
\hline Pill & $\begin{array}{l}-2.190 \\
(14.80)^{\star *}\end{array}$ & $\begin{array}{l}-2.621 \\
(16.03)^{* *}\end{array}$ & $\begin{array}{l}-2.496 \\
(7.87)^{\star *}\end{array}$ & $\begin{array}{l}-3.234 \\
(8.58)^{\star *}\end{array}$ \\
\hline IUD & $\begin{array}{l}-3.427 \\
(27.32)^{\star *}\end{array}$ & $\begin{array}{l}-4.064 \\
(29.55)^{\star *}\end{array}$ & $\begin{array}{l}-3.400 \\
(13.93)^{\star *}\end{array}$ & $\begin{array}{l}-4.296 \\
(13.67)^{\star *}\end{array}$ \\
\hline Other modern methods & $\begin{array}{l}-1.861 \\
(7.71)^{\star *}\end{array}$ & $\begin{array}{l}-2.119 \\
(7.59)^{* *}\end{array}$ & $\begin{array}{l}-4.365 \\
(4.34)^{\star *}\end{array}$ & $\begin{array}{l}-5.199 \\
(4.95)^{* *}\end{array}$ \\
\hline Constant & $\begin{array}{l}-3.422 \\
(14.83)^{\star *}\end{array}$ & $\begin{array}{l}-3.166 \\
(10.70)^{* *}\end{array}$ & $\begin{array}{l}-3.680 \\
(8.03)^{* *}\end{array}$ & $\begin{array}{l}-2.921 \\
(4.73)^{* *}\end{array}$ \\
\hline Gamma variance & & $\begin{array}{c}0.939 \\
(11.16)^{\star *}\end{array}$ & & $\begin{array}{l}0.342 \\
(1.69)\end{array}$ \\
\hline Log-Likelihood & -6004.1 & -5859.9 & -1207.9 & -1172.1 \\
\hline
\end{tabular}


Figure 8: Discrete time hazard with and without unobserved heterogeneity for women in the reference category

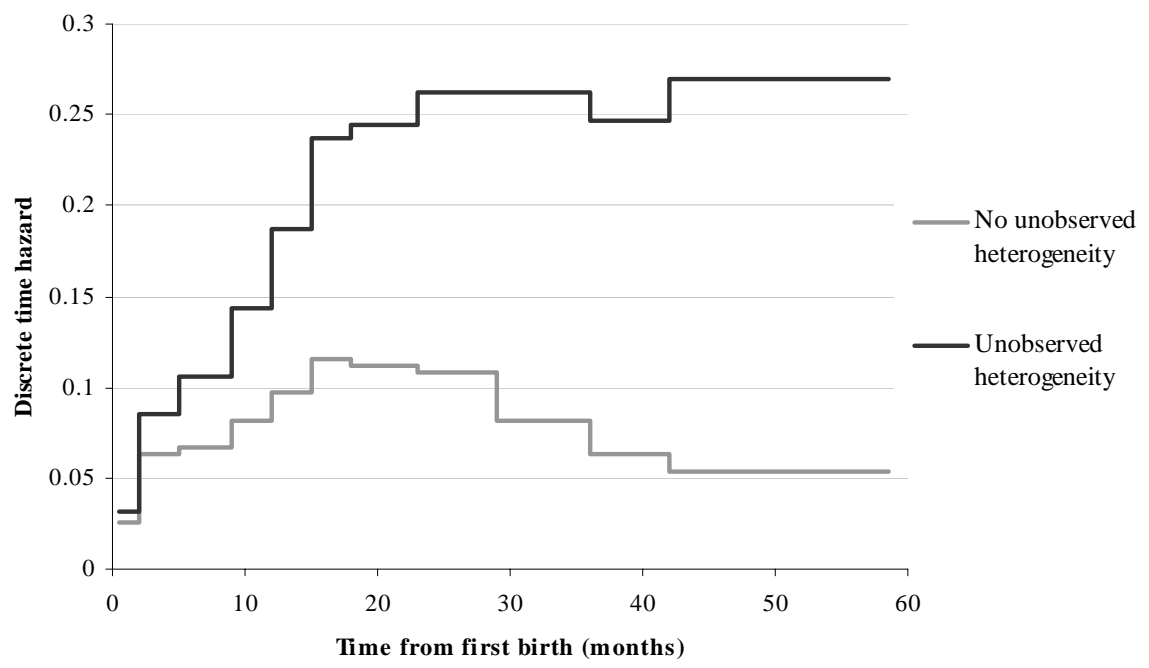

Note: In this figure the hazards at duration t months, $h(t)$, are calculated using models 4 and 5 in Table 6 using the equation $h(t)=\exp (b X) /[(1+\exp (b X)]$ where $b$ is a vector of parameter estimates and $X$ is the appropriate covariate vector. The covariate vector used in the calculations relates to the reference category on all covariates except duration and the time (in months) from marriage to first birth. The time from marriage to first birth was set at 19 months for all women. 


\section{Conclusion}

Using Bongaarts's (1982) framework of the proximate determinants of fertility, which shows that all important variation in fertility is captured by variation in the proximate determinants, this paper assesses the reliability of the Demographic and Health Survey (DHS) calendar data. Most previous assessments of the reliability of those data have used aggregate techniques. However, the question we pose here is not whether individual level responses of calendar data are reliable or not, but rather: are the calendar data good enough to capture all the 'measurable variation' in fertility?

Our results show that once the calendar data on the proximate determinants are fully incorporated into a model, social, economic and cultural factors become insignificant. This is particularly so when an unobserved heterogeneity term is included in the model to capture variation in those proximate determinants which are hard to measure directly. Hence, the paper shows that calendar data provides important information to enable demographers potentially to identify the pathways by which social and economic factors influence fertility.

The results of this analysis demonstrate the importance of introducing detailed month-by-month information on contraception in birth interval analysis. They also show that we should not only include in the analysis the period of breastfeeding but also the period of post-partum amenorrhoea. The results suggest that the inclusion in the model of socio-economic variables can improve our measurement of the impact of biological variables in a model which does not control for unobserved heterogeneity. However, when unobserved characteristics are controlled for by incorporating a heterogeneity term, the direct impact of socio-economic variables on the hazard of conception becomes very small.

The ability of the DHS calendar to measure the proximate determinants of fertility accurately opens up the possibility of using the calendar data to effect a decomposition of the mechanisms through which individual social and economic determinants act to influence fertility and to create observed fertility differentials. Probably the most promising method to use for this would be the 'fertility exposure analysis' of Hobcraft and Little (1984). Hobcraft and Little's model has been rather under-used over the past two decades, possibly because of its very demanding data requirements. The few extant attempts to establish how social and economic change operates through proximate determinants to influence fertility levels and trends have relied on particular data sets of exceptional detail (for example Gertler and Molyneaux, 1994, who use the 1987 National Indonesian Contraceptive Prevalence Survey, which has five-year histories of contraceptive use). The level of detail provided by the DHS calendar data would seem to make the application of 'fertility exposure analysis' more attractive, particularly as 
they allow the use of more exposure states than conventional retrospective survey data (see Hobcraft and Little, 1984: 23).

Despite the fact that the analysis reported in this paper was not designed to study contraceptive failure rates, it can help to provide some insight into contraceptive failure in Egypt. The results show a degree of failure of contraceptive use. The level of contraceptive failure varies by method, though a degree of failure is present in every method of contraceptive use. It seems that in Egypt the IUD is less prone to failure than the pill or other modern methods. This suggests that policy makers should not only look to increase uptake of contraceptive methods but improve family planning counselling, as contraceptive methods have still a degree of failure.

\section{Acknowledgments}

Angela Baschieri's contribution to this research was sponsored by the Economic and Social Research Council of the United Kingdom (grant number R42200134052). The authors would like to thank Prof. John Micklewright and the participants of the Social Statistics seminar series at the University of Southampton for useful comments on an earlier draft of this paper. 


\section{References}

Blossfeld, H.-P.and G. Rohwer. 1995. Techniques of event history modelling: new approaches to casual analysis. Mahwah, New Jersey: Lawrence Erlbaum Associates.

Bongaarts, J. 1978. 'A framework for analysing the proximate determinants of fertility.' Population and Development Review 4:105-132.

Bongaarts, J. 1982. 'The fertility-inhibiting effects of the intermediate fertility variables.' Studies in Family Planning 13:178-189.

Bumpass, L.L., R.R. Rindfuss, and P. James. 1986. 'Determinants of Korean birth intervals: the confrontation of theory and data.' Population Studies 40:403-423.

Curtis, S.L. 1997. 'Using calendar data to study contraceptive use.' Paper presented at the IUSSP/EVALUATION Project Seminar on Methods for Evaluating Family Planning Program Impact, May 14-16 1997, Costa Rica.

Curtis, S.L. and A.K. Blanc. 1997. Determinants of contraceptive failure, switching and discontinuation: an analysis of DHS contraceptive histories. Analytical Report no. 6. Calverton, MD: Macro International.

Davis, K.and J. Blake. 1956. 'Social structure and fertility: an analytic framework.' Economic Development and Cultural Change 4:211-235.

El-Zanaty, F. and A. Way. 2001. Egypt Demographic and Health Survey 2000.

Esseghairi, K. 2003. 'Sustaining fertility control in Tunisia while addressing emerging reproductive health needs: a comparison with Algeria.' Unpublished MPhil thesis, Department of Social Statistics, University of Southampton.

Gertler, P.J. and J.W. Molyneaux. 1994. 'How economic development and family planning programs combined to reduce Indonesian fertility.' Demography 31:3363.

Heckman, J.J. and B. Singer. 1982. 'The identification problem in econometric models for duration data.' In: Hildenbrand, W. ed., Advances in econometrics. Cambridge: Cambridge University Press, 39-77.

Hobcraft, J. and R.J.A. Little. 1984. 'Fertility exposure analysis: a new method for assessing the contribution of proximate determinants to fertility differentials.' Population Studies 38: 21-45. 
Hobcraft, J. and J. Mc Donald. 1984. 'Birth intervals. World Fertility Survey Comparative Studies no. 28. Voorburg, Netherlands: International Statistical Institute.

Jain, A., A. Hermalin and T.-H. Sun. 1979. 'Lactation and natural fertility.' In: Leridon, H. and Menken, J.

Jenkins, S.P. 1995. 'Easy estimation methods for discrete-time duration models.' Oxford Bulletin of Economics and Statistics 57:129-138.

Jenkins, S.P. 1997. 'Estimation of discrete time (grouped duration data) proportional hazards models: pgmhaz.' in Mimeo: ESRC Research Centre on Micro-Social Change, University of Essex.

Kallan, J. and J.R. Udry. 1986. 'The determinants of effective fecundity based on the first birth interval.' Demography 23:53-66.

Lancaster, T. 1979. 'Econometric methods for the duration of unemployment.' Econometrica 47:939-956.

Leone, T. 2002. 'Fertility and union dynamics in Brazil.' Unpublished PhD thesis, Department of Social Statistics, University of Southampton.

Magnani, R.J., N. Rutenberg, and H.G. McCann. 1996. 'Detecting induced abortions from reports of pregnancy terminations in DHS calendar data.' Studies in Family Planning 27:36-43.

McDonald, J. and P.J. Egger. 1990. 'Discrete-time survival model for the analysis of birth intervals.' Paper presented at the Annual Meeting of the Population Association of America. Toronto, Canada.

McNeilly, A.S. 1993. 'Breastfeeding and fertility'. In: Gray, R.H., Leridon, H. and Spira, A., eds. Biomedical and demographic determinants of reproduction. Oxford: Clarendon Press, 391-412.

Meyer, B.M. 1990. 'Unemployment insurance and unemployment spells.' Econometrica 58:757-782.

Palloni, A. 1984. 'Assessing the effects of intermediate variables on birth intervalspecific measure of fertility.' Population Index 50:623-657.

Prentice, R.L. and L.A. Gloecker. 1978. 'Regression analysis of grouped survival data with application to breast cancer data.' Biometrics 3:57-67. 
Rindfuss, R.R., J.A. Palmore, and L.L. Bumpass. 1987. 'Analyzing birth intervals: implications for demographic theory and data collection.' Sociological Forum 4:811-828.

Rodriguez, G. 1984. The analysis of birth intervals using proportional hazard models. World Fertility Survey Technical Report no. 2314. Voorburg, Netherlands: International Statistical Institute.

Rodriguez, G. and J. Hobcraft. 1983. Illustrative analysis: life table analysis of birth intervals in Colombia. World Fertility Survey Scientific Report no. 16. Voorburg, Netherlands: International Statistical Institute.

Steele, F. and S.L. Curtis. 2003. 'Appropriate methods for analyzing the effect of method choice on contraceptive discontinuation.' Demography 40:1-22.

Steele, F., S.L. Curtis and M. Choe. 1999. 'The impact of family planning service provision on contraceptive-use dynamics in Morocco.' Studies in Family Planning 30:28-42.

Stewart, M.B. 1996 'Heterogeneity specification in unemployment duration models.' Mimeo: Department of Economics, University of Warwick.

Strickler, J.A., R.J. Magnani, H.G. McCann, L.F. Brown and J.C. Rice. 1997. 'The reliability of reporting of contraceptive behaviour in DHS calendar data: evidence from Morocco.' Studies in Family Planning 28: 44-53.

Trussell, J., L.G. Martin, R. Feldman, J.P. Palmore, M. Concepcion and D.N.L.B.D.A. Bakar. 1985. 'Determinants of birth-interval length in the Philippines, Malaysia and Indonesia: a hazard-model analysis.' Demography 22:145-168.

Trussell, J., B. Vaughan and S. Farid. 1988. 'Determinants of birth interval length.' In: Hallouda, A.M., Farid, S. and Cochrane, S.H. eds, Egypt demographic responses to modernization. Cairo: Central Agency for Public Mobilization and Statistics.

Tukey, J.W. 1977. Exploratory data analysis. New York: Addison-Wesley.

Zhang, F., A.O. Tsui and C.M. Suchindran. 1999. The determinants of contraceptive discontinuation in Northern India: a multilevel analysis of calendar data. Measure Evaluation Working Papers WP-99-15. Chapel Hill, NC: Carolina Population Center, University of North Carolina.. 
Baschieri \& Hinde: The proximate determinants of fertility and birth intervals in Egypt 